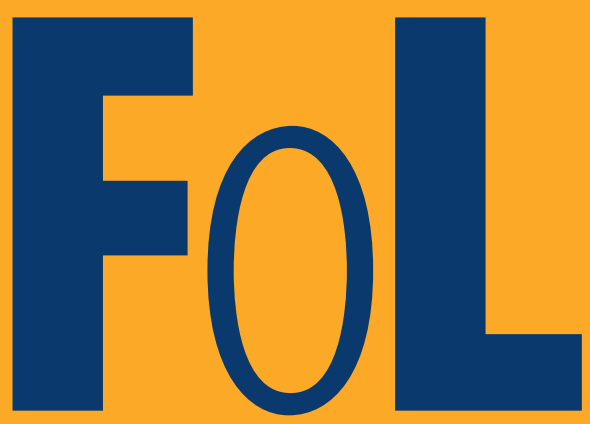

F O L I A

L I N G U I S T I C A Acta Societatis

Linguisticae Europaeae

Mouton de Gruyter 
FOLIA LINGUISTICA is the peer-reviewed journal of the Societas Linguistica Europaea. It appears in Spring and Autumn (ca. 450 pages in all) and covers all nonhistorical areas in the traditional disciplines of general linguistics (phonology, morphology, syntax, semantics, pragmatics), and also sociological, discoursal, computational and psychological aspects of language and linguistic theory. Other areas of central concern are grammaticalization and language typology.

The journal consists of scientific articles presenting results of original research, review articles, critical surveys of research in specific areas, book reviews, and a miscellanea section carrying brief descriptive reports and discussion notes.

Manuscript submission: Please consult the FoL style sheet (to be found at the FoL homepage www.folialinguistica.com).

Contact details: All correspondence concerning FOLIA LINGUISTICA should be sent to Prof. Dr. Teresa Fanego, Facultad de Filología, Universidad de Santiago de Compostela, 15782 Santiago de Compostela, Spain. E-mail: <teresa.fanego@usc.es>. FOLIA LINGUISTICA is indexed/abstracted in Academic OneFile; Arts \& Humanities Citation Index; Bibliographie Linguistique/Linguistic Bibliography; Bibliography of Linguistic Literature/Bibliographie Linguistischer Literatur (BLL); Cultures, Langues, Textes: La Revue de Sommaires; Current Contents/Arts \& Humanities; EBSCO Communication and Mass Media Index; EBSCO Current Abstracts; European Reference Index for the Humanities; IBR International Bibliography of Book Reviews of Scholarly Literature in the Humanities and Social Sciences; IBSS International Bibliography of the Social Sciences; Institut de l'Information Scientifique et Technique (INIST); International Bibliography of Periodical Literature in the Humanities and Social Sciences (IBZ); Linguistics Abstracts Online; Linguistics and Language Behaviour Abstracts; MLA International Bibliography; OCLC Electronic Collections Online; PsycINFO; Scopus; The Year's Work in English Studies.

Attention before copying: Authorization to copy items for internal or personal use, or for the internal or personal use by specific clients is granted by Walter de Gruyter, for libraries and other users registered with the Copyright Clearance Center (CCC) Transactional Reporting Service, provided that the base fee of US $\$ 3.00$ per copy is paid to CCC, 222 Rosewood Drive, Danvers, MA 01923, USA.

(C) 2009 by Walter de Gruyter GmbH \& Co. KG, D-10785 Berlin - Societas Linguistica Europaea.

All rights reserved, including those of translation into foreign languages. No part of this journal may be reproduced in any form without written permission from the copyright owners.

Cover design by Martin Zech, Bremen.

Typeset at the Department of English of the University of Santiago de Compostela.

Printed on recycled paper by Plana Artes Gráficas, Santiago de Compostela. 


\title{
Men, women, and birds. An embryonic system of noun classification in Ancient Greek ${ }^{1}$
}

\author{
Andrea Sansò \\ Università dell'Insubria - Como
}

In Ancient Greek, two terms meaning 'man' (anēr and anthroppos) combine with common nouns referring to human occupations, ethnic groups, and ranks in a generic-specific construction (e.g. anēr hiereus 'priest' [lit. 'man priest']; anēr Spartiatēs 'Spartan' [lit. 'man Spartan']). This construction is used to refer to male human referents in a clearly identifiable set of discourse contexts, including (i) numeral expressions, (ii) non-assertive contexts, and (iii) presentative sentences in which a character is introduced at the beginning of a more or less lengthy story about him. In all these contexts, the function of the two terms may be thought of as similar to the function of the indefinite article, i.e. the construction always introduces indefinite referents, which may be both specific (aner hiereus = 'a [certain] priest') and non-specific (anēr hiereus = 'a priest, any priest'). The pairing of a generic and a specific noun resembles the well-known pattern by which generic superordinate terms such as 'man', 'woman', 'animal', 'vegetable', 'bird', 'tree', etc. grammaticalize into noun classifiers, accompanying more specific nouns with a more restricted meaning. Besides classifying discourse referents, the main function of noun classifiers is determination/reference, i.e. they generally play a determinerlike role, marking the discourse status of their referents. Based on the available typological evidence on noun classifiers, in this paper I will argue for an interpretation of the construction anerr/anthrōpos + common noun as an incipient

\footnotetext{
${ }^{1}$ This paper profited greatly from discussions with Caterina Mauri (Università di Pavia) and especially Colette Grinevald (Université Lumière, Lyon 2), whose many insightful remarks have pointed out some weak points in the argumentation and have eventually led to clarifications in the final text. Thanks are also due to the audience of the VII Incontro Internazionale di Linguistica Greca (Cagliari, September 2007), where a preliminary version of this paper was presented. Responsibility for any remaining errors or shortcomings is mine alone.
}

Folia Linguistica 43/1 (2009), 95-133.

ISSN 0165-4004, E-ISSN 1614-7308 @ Mouton de Gruyter - Societas Linguistica Europaea DOI: FLIN.2009.003 
classifier construction, i.e. a non-obligatory construction, preferentially associated with an identifiable set of discourse situations, in which a free-form lexeme with superordinate semantics is combined with a more specific noun. Classifier constructions are considered to be the first stage in the grammaticalization path leading from generic superordinate nouns to noun classifiers. Similar uses of other superordinate terms such as gyne 'woman' and ornis 'bird' are also discussed. These uses are suggestive of a rudimentary system of nominal classification in Ancient Greek. In the conclusions, I will provide some speculative thoughts on why this system has not eventually developed into a full system of noun classifiers.

Keywords: noun classifiers, classifier constructions, Ancient Greek

\section{The problem}

In Septuagint and New Testament Greek, two terms meaning 'man', anthrōpos and, more rarely, anēr, can be used alone as equivalents for the

2 Three stages are traditionally distinguished in the history of Ancient Greek: (i) the
PRE-CLASSICAL PERIOD (from the 8th to the 5th centuries BC) is characterized by the
coexistence of many literary standards. Each of them is characteristic of a given
literary genre, although all display traditional poetic features derived from HoMERIC
GREEK, the language of the Iliad and the Odyssey, "essentially an archaic eastern Ionic
but with an admixture of Aeolic, and a number of conspicuous archaisms not
characteristic of any historical dialect or region" (Horrocks 1997: 18). By the end of
this period, Ionic had emerged as the language of literary prose and had become the
model for prose writers even outside Ionia. The term (ii) CLASSICAL GREEK will be
used in this paper to refer to the language of literature developed "in a purely
Athenian context during the late 5th and early 4 th centuries BC" (Horrocks 1997:
26). The term (iii) HELLENISTIC GREEK is used as a general label covering the written
standard of the Hellenistic world (from the latter half of the 4 th century BC
onwards). An equivalent term is KoINE GREE. This language can be seen as a highly
standardized evolution of Classical (Attic) Greek, used for administrative and
scholarly purposes and as a universal prose language. SEPTUAGINT and NEW
TESTAMENT GREE refer to two special varieties of Hellenistic Greek: Septuagint
Greek is the language used in the Greek translation of the Old Testament, made in
the 3rd-2nd centuries BC, while New Testament Greek is the language of the New
Testament, composed directly in Greek "in the main by men without a higher
education ... and written in an area where Aramaic was the first language of the
majority" (Horrocks 1997: 92). Both these varieties are generally considered as 
indefinite adjective/pronoun tis '(some/any)-one', in various contexts ranging from species-generic generalizations such as (1) to non-assertive contexts such as those exemplified in (2) and (3) (a hortative and a hypothetical context, respectively): ${ }^{3}$

(1)

$\begin{array}{lcccc}\text { ou } & \text { dikaioutai } & \text { anthrōpos } & \text { eks } & \text { ergōn } \\ \text { NEG } & \text { justify:PASS.PRS.3SG } & \text { man:NOM.SG } & \text { from } & \text { work:GEN.PL } \\ \text { nomou } & \text { ean mē dia } & \text { pisteōs } & \text { Iēsou Khristou }\end{array}$

law:GEN.SG if NEG through faith:GEN.SG Jesus:GEN Christ:GEN

'a man/one is not justified by the works of law, but by faith in Jesus

Christ' (Galatians 2, 16)

$(2)$

$\begin{array}{lllll}\text { houtōs } & \text { hēmas } & \text { logizesthō } & \text { anthrōpos } & \text { hōs } \\ \text { thus } & \text { PRO.1PL:ACC } & \text { consider:IMP.PRS.3SG } & \text { man:NOM.SG } & \text { as } \\ \text { hypēretas } & \text { Khristou } & & & \end{array}$

servant:ACC.PL Christ:GEN

'one should look on us as Christ's servants' (I Cor. 4, 1; transl. H. G. May \& B. M. Metzger)

(3)

$\begin{array}{llll}\text { ean kai prolēmphthē } & \text { anthrōpos } & \text { en tini } \\ \text { if also catch:PASS.AOR.3SG } & \text { man:NOM.SG in } & \text { any:DAT } \\ \text { paraptōmati ... } & & & \\ \text { wrongdoing:DAT } & \end{array}$

'if someone is caught in any kind of wrongdoing' (Galatians 6, 1; transl.

H. G. May \& B. M. Metzger)

Both anthrōpos and anēr have indefinite meaning also when used in combination with common nouns referring to human occupations, ethnic groups, and ranks, as in examples (4)-(7). In these cases, the function of anēr

reflecting a more or less direct influence from contemporary Aramaic (see also footnotes 6 and 7 below).

${ }^{3}$ The following transliteration conventions have been adopted: the Greek letters theta, phi, and chi are transliterated as $t h, p h$, and $k h$ respectively; the letter $x i$ is transliterated as $k s$; the letter gamma is rendered as $n$ when a kappa, a chi, or another gamma follow; upsilon is rendered as $u$ when following another vowel, otherwise it is rendered as $y$; the rough breathing (') is rendered by means of a word-initial $h$, except when it precedes a $r h o$, in which case the notation $r h$ is adopted; long $e$ and $o$ (eta and omega) are rendered as $\bar{e}$ and $\bar{o}$; the iota is omitted in long digraphs with iota subscript; accents are not marked. In the interlinear glosses, verbal categories are attached to the lexical item in the following order: VOICE (passive; active is not glossed); MOOD (subjunctive, optative, imperative, infinitive, participle; indicative is not glossed); TENSE/ASPECT (present, imperfect, aorist, perfect); PERSON/NUMBER. 
and anthroppos resembles that of the indefinite article. In (4) anthroppos dynastēs has generic reference (= 'a lord, a master') in a gnomic context. In (5) anthrōpos hiereus refers to any member of the set of priests. In (6) anēr phoneus has indefinite reference, though it identifies a specific member of the set of murderers (= 'a (certain) murderer'). Similarly, in (7), the referent of the NP anthropos hiereus is a specific member of the set of priests (= 'a (certain) priest').

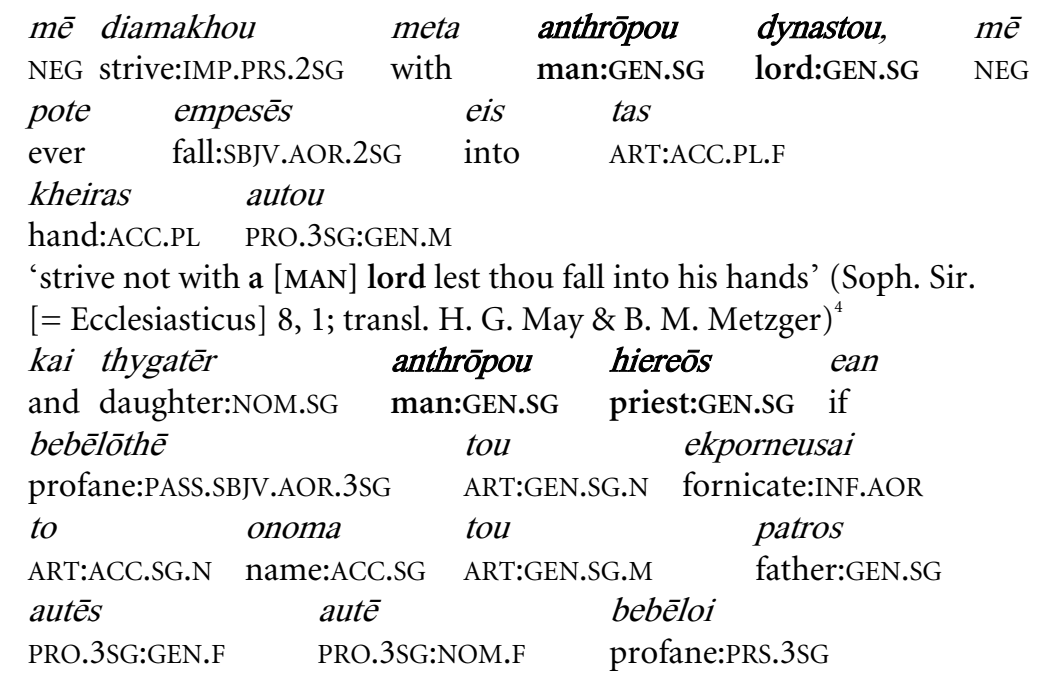

'and the daughter of a [MAN] priest, if she profanes herself by playing the harlot, profanes her father's name' (Leviticus 21, 9; transl. H. G. May \& B. M. Metzger, adapted)

(6) kai ètēsasthe and ask:AOR.2PL kharisthēnai hymin grant:PASS.INF.AOR PRO.2PL:DAT

'[but you denied the Holy and Righteous One], and asked for a [MAN] murderer to be granted to you' (Acts 3, 14; transl. H. G. May \& B. M. Metzger)

(7)

$\begin{array}{lllll}\text { anthropos } & \text { hiereus } & \text { ek } & \text { tou } & \text { spermatos } \\ \text { man:NOM.SG } & \text { priest:NOM.SG } & \text { from } & \text { ART:GEN.SG.M } & \text { seed:GEN.SG }\end{array}$

\footnotetext{
${ }^{4}$ [MAN] and $[\varnothing]$ in the translations of the Greek passages are used as conventional notations to indicate, respectively, the use of aner/anthrōpos in combination with a common noun, or its absence.
} 


$\begin{array}{lllll}\text { Aarōn ellthen } & \text { en } & \text { tais } & \text { dynamesin } \\ \text { Aaron come:AOR.3SG } & \text { in } & \text { ART:DAT.PL.F } & \text { forces:DAT } \\ \text { 'a [MAN] priest of the line of Aaron has come with the army, [and he will } \\ \text { not harm us]' (I Macc. 7, 14; transl. H. G. May \& B. M. Metzger) }\end{array}$

The uses illustrated in (1)-(7) stretch over a continuous area of the functional domain of SPECIFICITY/DEFINITENESS as defined e.g. by Givón (1984: 407ff): anthrōpos and anēr cover GENERIC ((1) and (4)), NON-SPECIFIC INDEFINITE ((2), (3) and (5)), and SPECIFIC INDEFINITE referents $((6)$ and (7)). ${ }^{5}$ The functions of the two terms do in fact largely overlap with the range of functions of the indefinite adjective/pronoun tis. A consequence of this functional similarity is that aner and anthropos, though syntactically nouns, are generally treated under the heading of "indefinite pronouns" or "quasipronouns" in grammars and lexicons of Old and New Testament Greek (see e.g. Thackeray 1909: 45; Blass \& Debrunner 1961: 158; Danker 2000, s.v. anêr, p. 79; s.v. anthrōpos, p. 81: "practically equiv[alent] to the indef[inite] pron[oun], w[ith] the basic m[eani]ng of a[nthropos] greatly weakened"). Table 1 displays the indefinite uses of the two terms in Old and New Testament Greek, classified according to their degree of specificity/definiteness:

\footnotetext{
${ }^{5}$ In Givón's terms, DEFINITENESS is a complex domain, which encroaches upon another semantic dimension, namely SPECIFICITY (or REFERENTIALITY), defined as "the speaker's intent to refer to some individual" (Givón 1984: 390). A linguistic item has generic reference if it refers to a class of individuals (The lion is dangerous / Lions are dangerous); it is non-specific indefinite if the speaker does not have a specific entity in his/her mind, and at the same time s/he does not want the hearer to infer that such a specific entity exists (Even a child can understand this); it is specific indefinite if it refers to a specific entity which has not been mentioned before or which cannot be identified more precisely (He bought a book). Finally, an item is definite if the speaker assumes that the hearer knows, assumes, or can infer that particular item, even if $s /$ he is not necessarily thinking about it (If you see the man with the green hat there, tell him...).
} 


\begin{tabular}{llll}
\hline Generic & $>$ & $\begin{array}{l}\text { Non-specific } \\
\text { indefinite }\end{array}$ & Specific indefinite (> Definite) \\
\hline anthrōpos alone, ex. (1) & anthrōpos alone, & anthrōpos/anēr+ \\
anthrōpos/anēr+ & exx. (2)-(3) & common noun, \\
common noun, ex. (4) & $\begin{array}{l}\text { anthropos/anēr }+ \\
\text { common noun, ex. }\end{array}$ & \\
& $(5)$ & \\
& & \\
&
\end{tabular}

Table 1. The generic/indefinite uses of anthropos and anēr in Old and New Testament Greek

These uses are generally credited to the Semitic influence on Septuagint ${ }^{6}$ and New Testament Greek (Thackeray 1909: 45; Black 1967: 106; Bonfante 1980; Bubenik 1989: 66-67, among others). In his analysis of New Testament Greek, for instance, Wellhausen explicitly postulates a direct derivation of this pattern from Aramaic:

${ }^{6}$ The Semitic character of Septuagint Greek is one of the most debated issues in the history of the Greek language, and cannot be dealt with in detail here. The dominant trend in the current literature is to maintain (as do, among others, Gehman 1951 and Horrocks 1997: 56ff) that Septuagint Greek is Hellenistic Greek to full right, reflecting the everyday language spoken in Alexandria in Egypt. Its many unusual features can be attributed to the difficulties of translating - for the first time in the history of the Greek language - an Eastern religious work. The presence of Semitisms cannot be denied, "especially where the obscurity or formulaic language of the original led to literalness" (Horrocks 1997: 57), but the analysis of contemporary Egyptian documents proves that the lexical and grammatical characteristics of Septuagint Greek are also typical of contemporary Egyptian Greek. Others recognize a notable contrast between Jewish texts written directly in Greek and Old Testament Greek, the latter being profoundly "Semitized": "the kind of Greek found in the Pentateuch is confined to books that are known to be translations ... Jewish works composed originally in Greek show nothing like the same degree of Semitic influence" (Lee 1983: 15).

${ }^{7}$ As far as the New Testament is concerned, the current debate includes different positions, "[ranging from] positing a pure koine derived directly from Attic Greek to a heavily Semitized translation Greek, and all points in between" (Porter 1989: 113114). New Testament books have been written directly in Greek, and thus it is more problematic to unravel the "Semitic" (or, more precisely, Aramaic) features of this variety of Greek from the "popular" ones. It is fairly uncontroversial, however, that "at the basis of the Greek Gospels ... there must lie a Palestinian Aramaic tradition, at any rate of the sayings and teaching of Jesus, and this tradition must at one time have been translated from Aramaic into Greek" (Black 1967: 16). Whether or not the 
Zur stärkeren Hervorhebung der Indetermination wird öfters das Zahlwort heis statt tis angewandt ... In gleicher Weise anthrōpos bei Matthäus: ekhthros

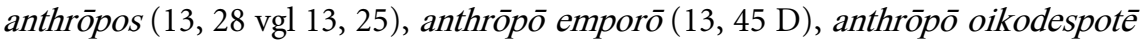
(13, 52. 20, 1. 21, 33), anthrōpo basilei $(18,23)$ - vergeblich sucht man zu leugnen, daß hier anthrōpos etwas anderes sei als das aramäische $\mathrm{n} \mathbf{a} \mathrm{sch}$, welches im Status absolutus für quidam gebraucht und den Hauptwörtern voroder nachgesetzt wird (Wellhausen 1911: 20, my emphasis). ${ }^{8}$

The Semitic character of these uses is further corroborated by the fact that in Septuagint Greek anēr and anthrōpos are used more frequently with indefinite sense in a group of books "in which we see the beginnings of the tendency towards pedantic literalism" (Thackeray 1909: 10). . Yet, while anthropos alone used as an equivalent of the indefinite pronoun is rarely - if ever - attested before the Septuagint, the use of aner/anthroppos + common noun with indefinite meaning is already well-established in Pre-classical and Classical Greek, and therefore it cannot be reasonably ascribed to the influence of a Semitic language.

Moreover, whatever their ultimate provenance, the two uses (anthropos used alone and aner/anthroppos + common noun) are instances of two different grammaticalization processes, and thus they possibly represent two phenomena not so strictly intertwined as they are traditionally deemed to be. The indefinite use of anthropos alone appears to be an instance of a process whereby generic terms meaning 'man' grammaticalize into indefinite pronouns (Giacalone Ramat \& Sansò 2007a; see also Haspelmath 1997: 182183; Heine \& Kuteva 2002: 208-209). The eventual outcome of this process are bona fide indefinite pronouns such as French on (< Latin homo) and German man, i.e. elements that can be used with both specific and non-

Evangelists themselves were the translators of these Aramaic sources, it is remarkable that in the New Testament the majority of passages in which anthropos is used as an indefinite element "come from sayings of Jesus" (Black 1967: 107).

8 'The numeral heis is used quite often instead of tis in order to reinforce the indeterminate sense ... Anthropos is used in Matthew's Gospel in the same way: ekhthros anthrōpos $(13,28$ cf. 13, 25), anthrōpō emporō (13, 45 D), anthrōpō oikodespotē $(13,52.20,1.21,33)$, anthrōpo basilei $(18,23)$ - it cannot reasonably be denied that in these passages anthrōpos is something other than Aramaic nâsch ['man', AS], which is used in status absolutus as an equivalent of quidam and is placed either before or after the main noun'.

${ }^{9}$ The books in question are Judges, Ruth, I Samuel, II Samuel, I Kings, II Kings, and Esdra. 
specific indefinite reference, and have taken on some behavioural properties of pronouns. The reader is referred to Giacalone Ramat \& Sansò (2007a: 106ff), where the semantic and formal aspects of this grammaticalization path (schematized in Figure 1) are discussed at length.

\begin{tabular}{ll}
\hline $\begin{array}{l}\text { (a) 'man' as species- } \\
\text { generic }\end{array}$ & $\begin{array}{l}\text { (b) 'man' as } \\
\text { non-specific } \\
\text { indefinite }\end{array}$ \\
\hline noun - (c) 'man' as specific indefinite \\
\hline French on, German man, etc. & $\begin{array}{l}\text { (E.g. French: On a tué le President } \\
\text { 'someone murdered the President' / } \\
\text { 'the President has been murdered'; } \\
\text { German: Man hat letzte Woche bei }\end{array}$ \\
& $\begin{array}{l}\text { uns eingebrochen 'someone burgled } \\
\text { our house last week' / 'our house was } \\
\text { burgled last week') }\end{array}$ \\
\hline Greek anthropos, Late Latin homo, etc. & \\
\hline
\end{tabular}

Figure 1. The grammaticalization path 'man' > indefinite pronoun (based on Giacalone Ramat \& Sansò 2007a: 106)

Greek anthrōpos, as well as Late Latin homo (Giacalone Ramat \& Sansò, to appear) behave syntactically as full NPs, and thus cannot be considered as indefinite pronouns. Yet, from a semantic point of view, both can be used with non-specific indefinite reference (i.e. they have reached stage (b) on the grammaticalization path sketched in Figure 1).

On the other hand, the use of anēr/anthrōpos + common noun resembles a different grammaticalization process by which generic superordinate nouns with meanings such as 'man', 'woman', 'animal', 'vegetable', 'bird', 'tree', etc. grammaticalize into NOUN CLASSIFIERS accompanying more specific nouns with a more restricted meaning. Noun classifiers are items "which refer to a general category ... and the specific noun with which they co-occur is typically ... a member of the category indicated" (Wilkins 2000: 151), as in the following Jakaltek and Yidiny examples.

(8) Jakaltek (Mayan; Craig 1986b: 264)

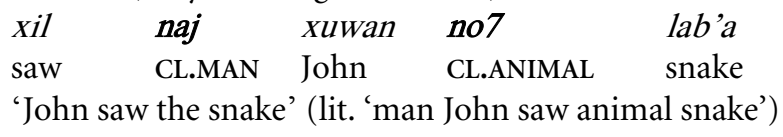


(9) Yidiny (Australian, Pama-Nyungan; Dixon 1982: 185)

$\begin{array}{llll}\begin{array}{l}\text { mayi } \\ \text { CL.VEGETABLE:ABS }\end{array} & \text { jamirr } & \text { bama-al } & \text { yaburu-ngu } \\ \text { julaal } & \text { CL.PERSON-ERG } & \text { girl-ERG } \\ \text { dig:PST } & & \\ \text { 'the girl dug up the yam' (lit. 'person girl dug up vegetable yam') }\end{array}$

The cross-linguistic behaviour of noun classifiers (also called GENERICS in the Australianist tradition; cf. Sands 1995) is far from homogeneous and it is difficult "to determine the difference between languages that have a true system of noun classification and those in which generic nouns may precede a more specific noun" (Sands 1995: 270, my emphasis). Some languages have a full set of noun classifiers, and every noun (or the vast majority of nouns) must appear with a classifier under precise syntactic or pragmatic conditions. In other languages it is more appropriate to speak of GENERIC-SPECIFIC CONSTRUCTIONS (or CLASSIFIER CONSTRUCTIONS; see below, Section 3.1), i.e. constructions with different degrees of optionality whose use appears to be favoured by precise discourse conditions.

In this paper, I will explore the plausibility of interpreting the Ancient Greek construction anēr/anthrōpos + common noun as a classifier construction, and will provide arguments in favour of such an analysis. The paper is organized as follows. In Section 2 I will examine the contexts of use of aner and anthrōpos + common noun, identifying some typical textual "environments" in which this construction appears with more than chance frequency. These textual environments include: (i) numeral expressions; (ii) non-assertive contexts; and (iii) presentative expressions in which a discourse referent is introduced at the beginning of a more or less lengthy story about him. Section 3 will be devoted to the analysis of aner/anthroppos + common noun as a classifier construction. The construction will be analyzed in the light of the main findings of the typological literature on noun classifiers, in which the connection between the use of noun classifiers and certain discourse/textual conditions has been extensively explored. Similar uses of other generic nouns such as gyne 'woman', and ornis 'bird' are also discussed: these uses are suggestive of a rudimentary system of nominal classification in Ancient Greek. Finally, in Section 4 I will provide some speculative thoughts on why these constructions have not eventually developed into a full system of noun classification. 


\section{Anēr and anthrōpos + common noun in Ancient Greek: a survey}

Grammars of Old and New Testament Greek generally signal the classical and pre-classical forerunners of anēr and anthrōpos + common noun. In grammars of (Pre)-Classical Greek, on the contrary, this use is mostly overlooked. One notable exception is Kühner (1898):

Viele ein Geschäft oder einen Stand oder ein Alter bezeichnende Personennamen behandelt die griechische Sprache als Adjektive ... und fügt denselben das Wort anēr hinzu, wenn der Mensch nach seinem Geschäfte oder Stande oder Alter betrachtet werden soll, indes das Wort anēr weggelassen wird, wenn der Mensch als in der Funktion eines Amtes oder Geschäftes begriffen betrachtet wird; so bedeutet anēr mantis ... einen Mann, der seinem Stande nach ein Seher ist, und mantis allein einen Mann, der als Seher auftritt; in der Dichtersprache wird aber auch ohne den angegebenen Unterschied anēr hinzugefügt ... Im verächtlichen Sinne wird anthrōpos hinzugefügt. (Kühner 1898: 271-272, my emphasis) ${ }^{10}$

According to Kühner, the semantic/pragmatic difference between simple common nouns and the construction anērlanthroppos + common noun is often a subtle one: the latter is favoured whenever what is profiled is the status/activity/rank as a "defining" component of the referent. On the contrary, when the discourse is about a referent serving a given function or performing a given activity, anēr and anthrōpos are generally omitted. In other words, aner mantis is an "identifying" description of the referent as being a member of the class of seers, whereas mantis (or mantis tis) is used when introducing a discourse referent who acts as seer in a given context. This difference is, however, quite unsystematic, as Kühner himself admits, and the distinction between common noun alone and common noun + anēr/anthrōpos is generally blurred in poetry.

\footnotetext{
${ }^{10}$ 'The Greek language treats many common nouns that refer to a man's activity, status or age as adjectives ... and adds the word anēr to them if the man is to be considered in terms of his activity, status or age, whereas the word anēr is omitted if the man is to be seen as engaged in the (typical) function connected to a rank or activity; thus, aner mantis means a man who is a seer by status, and mantis alone a man who acts as seer. In the poetic language, however, aner $r$ is added even in the absence of the aforementioned difference. When the sense is derogatory, anthropos is added.'
} 
Kühner's visionary insights are partially underpinned by corpus data. Consider, for instance, examples (10) to (13). In (10) and (11) a seer (expressed by mantis tis 'seer INDEF_ADJ') is depicted while performing his typical function:

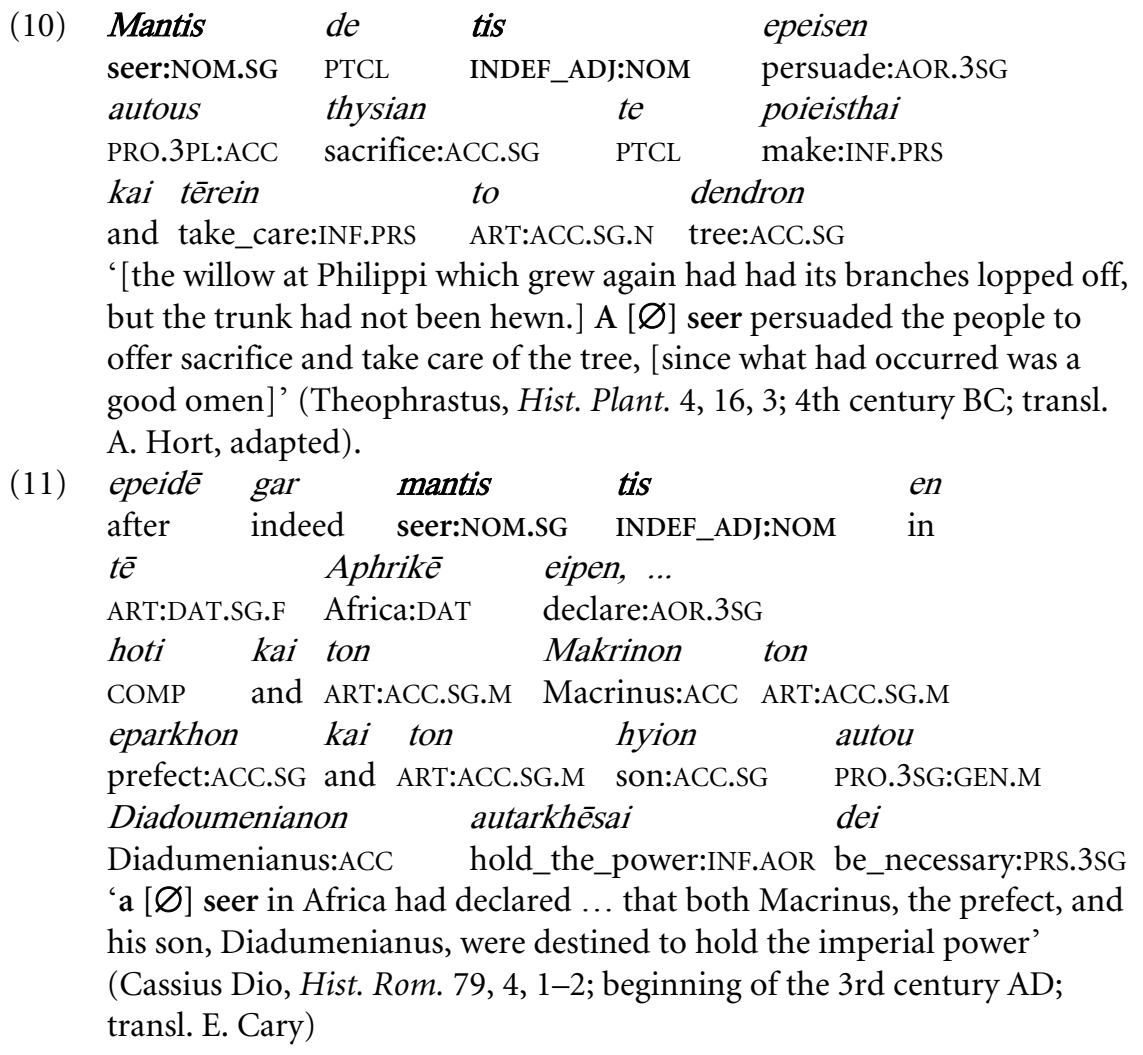

In (12) and (13), in which the construction aner mantis 'man seer' is used, what is at stake is the description of the inherent nature of the character (i.e. his being a seer).

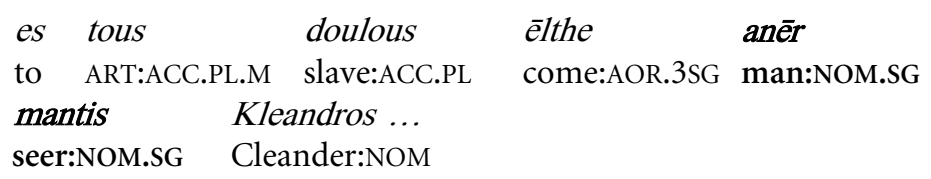


'[For a while they were at peace with each other; but presently] there came to the slaves one Cleander, a [MAN] prophet, [a man of Phigalea in Arcadia by birth; he persuaded the slaves to attack their masters. From this and for a long time there was war between them, till at last with much ado the Argives got the upper hand]' (Herodotus 6, 83; 5th century BC; transl. A. D. Godley)

(13)

\begin{tabular}{|c|c|c|c|}
\hline Eleusiniois & polemousi & \multicolumn{2}{|c|}{ pros } \\
\hline Eleusinian:DAT.PL & make_war:PTCP.PRS & DAT.PL & nst \\
\hline Erekhthea & $a n \bar{e} r$ & mantis & èlthen \\
\hline Erechtheus:ACC & man:NOM .SG & seer:NOM.SG & come:AOR.3SG \\
\hline ek $\quad$ Dōdōnēs & onoma & Skiros ... & \\
\hline Dodona:G & name:ACC.SG & Scirus:NOM & \\
\hline
\end{tabular}

'the Eleusinians were making war against Erechtheus when there came from Dodona a [MAN] seer called Scirus, [who also set up at Phalerum the ancient sanctuary of Athena Sciras. When he fell in the fighting the Eleusinians buried him near a torrent, and the hero has given the name to both place and torrent]' (Pausanias, Graeciae descriptio 1, 36; 2nd century AD; transl. W. H. S. Jones)

Example (14) illustrates the typical pairing of anēr and nouns indicating winners of games, a crystal-clear example of the defining function of the construction (the character's role in the context is obviously not related to his being a winner in the games).

(14) tēs êrkhe aner

REL:GEN.SG.F hold_command:IMPF.3SG man:NOM.SG

tris pythionikēs

Phaÿllos

three_times victor_in_Pithian_games:NOM.SG Phaÿllus:NOM '[ of those that dwell farther off than these, the men of Croton alone came to aid Hellas in its peril, and they with one ship], whereof the captain was Phaÿllus, a [MAN] victor in the Pithian games' (Herodotus 8, 47; transl. A. D. Godley)

Other passages show that Kühner's account is only partially correct. Take, for instance, (15): here a character introduced by the construction anēr halieus, lit. 'man fisher', actually performs the role of fisherman in the story.

$\begin{array}{ll}\text { anēr } & \text { halieus } \\ \text { man:NOM.SG } & \text { fisher:NOM.SG }\end{array}$

labōn

ikhthyn

take:PTCP.AOR.NOM.SG

fish:ACC.SG 


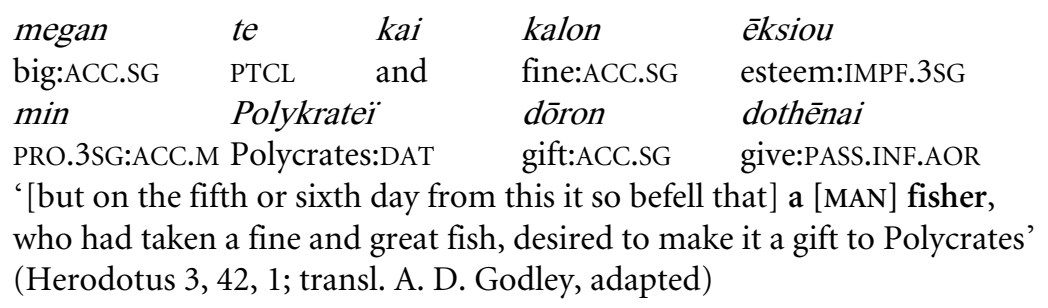

With ethnonyms, on the other hand, no significant differences can be found between the use of the ethnonym alone and the construction anerr + ethnonym. The following passages from Thucydides should serve as an illustration of the similarity of the contexts in which the construction aner Spartiatēs (lit. 'man Spartan'; cf. (16)-(17)), and the simple noun Spartiatēs 'Spartan' ((18)-(19)), occur:

\begin{tabular}{lllll} 
etykhe & \multicolumn{1}{c}{ de } & peri & tous & khōrous \\
happen:AOR.3SG & PTCL & near & ART.ACC.PL.M region \\
toutous & Brasidas & ho & \multicolumn{1}{c}{ Tellidos } \\
that:ACC.PL & Brasidas:NOM & ART:NOM.SG.M & Tellis:GEN \\
anēr & Spartiatēs & phrouran \\
man:NOM.SG & Spartan:NOM.SG & garrison:ACC.SG \\
ekhōn & & & &
\end{tabular}

have:PTCP.PRS.NOM.SG

'but Brasidas, son of Tellis, a [MAN] Spartan, happened to be in that neighbourhood with a guarding party, [and seeing the situation he set out with one hundred hoplites to relieve the garrison]' (Thucydides 2, 25, 2; 5 th century BC; transl. Ch. Forster Smith)

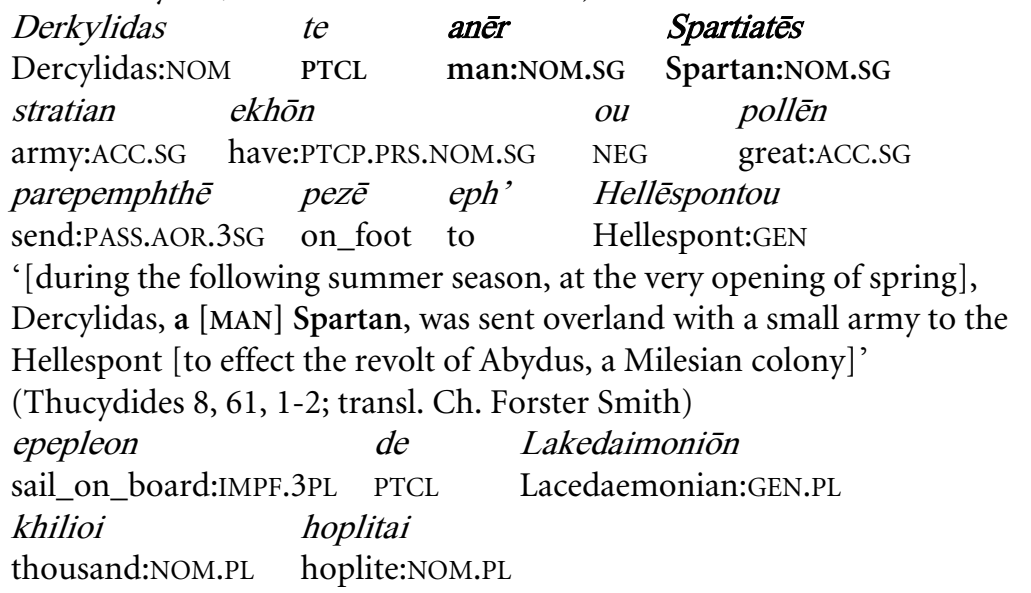




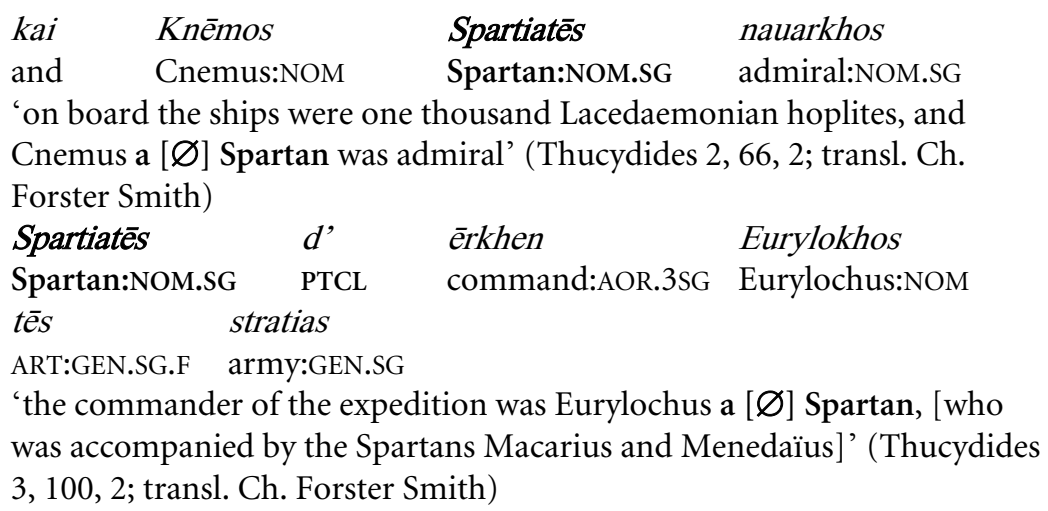

These passages also illustrate the low degree of systematicity of the construction in point. In many cases there are no evident semantic/pragmatic differences between this construction and the use of the common noun alone, so that Kühner appears to be fully justified in treating this variation as merely stylistic.

Yet, a "stylistic" variant may be indicative of an incipient grammaticalization process, especially if we manage to identify some contextual circumstances that favour its use. This is precisely the case of the construction aner/anthroppos + common noun in Ancient Greek. This construction appears to be favoured by a clearly identifiable set of discourse contexts. First, it appears frequently in NUMERAL EXPRESSIONS, especially (but not exclusively) when dealing with small numbers, as the following examples show:

$\begin{array}{llll}\text { pempei } & \text { angelous } & \text { es Makedoniēn } \\ \text { send:PRS.3SG } & \text { messenger:ACC.PL to Macedonia:ACC } \\ \text { andras } & \text { hepta Persas } & \\ \text { man:ACC.PL } & \text { seven Persian:ACC.PL }\end{array}$

'[so those of the Paeonians who were taken were carried into Asia. Then Megabazus, having made the Paeonians captive], sent as messengers into Macedonia [MEN] seven Persians [who (after himself) were the most honourable in his army]' (Herodotus 5, 17; transl. A. D. Godley, adapted)

$\begin{array}{llll}\text { epanisteatai } & \text { andres } & \text { magoi } & d y o \\ \text { rebel_against:PRS.3PL } & \text { man:NOM.PL } & \text { Magian:NOM.PL } & \text { two }\end{array}$




\section{adelpheoi}

brother:NOM.PL

'[now after Cambyses son of Cyrus had lost his wits, while he still lingered in Egypt], [MEN] two Magians, who were brothers, rebelled against him. [One of them had been left by Cambyses to be steward of his house]' (Herodotus 3, 61; transl. A. D. Godley, adapted)

$\begin{array}{lllc}\text { apopempousin } & \text { hoi } & \text { Lakedaimonioi } & \text { es } \\ \text { send:PRS.3PL } & \text { ART:NOM.PL.M } & \text { Lacedemonian:NOM.PL to } \\ \text { Korinthon } & \text { andras } & \text { Spartiatas } & \text { treis } \\ \text { Corinth:ACC } & \text { man:ACC.PL } & \text { Spartan:ACC.PL } & \text { three }\end{array}$

'the Lacedemonians sent to Corinth [MEN] three Spartans, [that they might as quick as possible haul the ships over the Isthmus from the Corinthian Gulf to the sea on the side toward Athens, and give orders for the whole fleet to sail to Chios - the ships which Agis was getting ready for Lesbos as well as the rest]' (Thucydides 8, 7; transl. Ch. Forster Smith)

The construction is also frequently used to introduce non-specific indefinite arguments in NON-ASSERTIVE CONTEXTS, i.e. when the argument is under the scope of operators such as negators, temporal and hypothetical subordinators such as if, when, etc.:

$\begin{array}{lccc}\text { en te } & \text { gar } & \text { katelēs } & \text { andra } \\ \text { if PTCL } & \text { indeed lay_low:SBJV.AOR.2SG } & \text { man:ACC.SG } \\ \text { stratēgon, } & \text { mega } & \text { toi } & \text { ginetai } \\ \text { general:ACC.SG } & \text { great:NOM.SG.N } & \text { PRO.2SG:DAT happen:PRS.3SG }\end{array}$
'[to my mind, it is right that king and general should by king and general be encountered.] For if you lay low a [MAN] general, you have achieved a great feat; [and failing that, if he lay you low (as I pray he may not), it is but half the misfortune to be slain by a noble foe]' (Herodotus 5, 111; transl. A. D. Godley, adapted)

$\begin{array}{lll}\begin{array}{l}\text { hösper an } \\ \text { as_if }\end{array} \text { tis } & \text { peri anthrōpou } \\ \text { hyphantou } & \text { INDEF_PRO } & \text { about man:GEN.SG } \\ \text { presbytou } & \text { apothanontos } \\ \text { weaver:GEN.SG } & \text { old:GEN.SG } & \text { die:PTCP.AOR.GEN.SG } \\ \text { legoi } & \text { touton } & \text { ton logon } \\ \text { say:OPT.PRS.3SG } & \text { this:ACC.SG } & \text { ART:ACC.SG.M discourse:ACC.SG } \\ \text { '[what's being said, I think, is very much] as if someone should offer this } \\ \text { argument about a [MAN] weaver who has died in old age [to show that the } \\ \text { person hasn't perished but exists somewhere intact, and should produce } \\ \text { as evidence the fact that the cloak he had woven for himself, and worn, }\end{array}$


was intact and had not perished]' (Plato, Phaed. 87b; 4th century BC; transl. H. N. Fowler)

GNOMIC CONTEXTS such as (25) and (26) are another typical discourse environment in which the construction anerranthropos + common noun is often found. They share with non-assertive contexts the non-factuality of the state of affairs depicted by the clause.

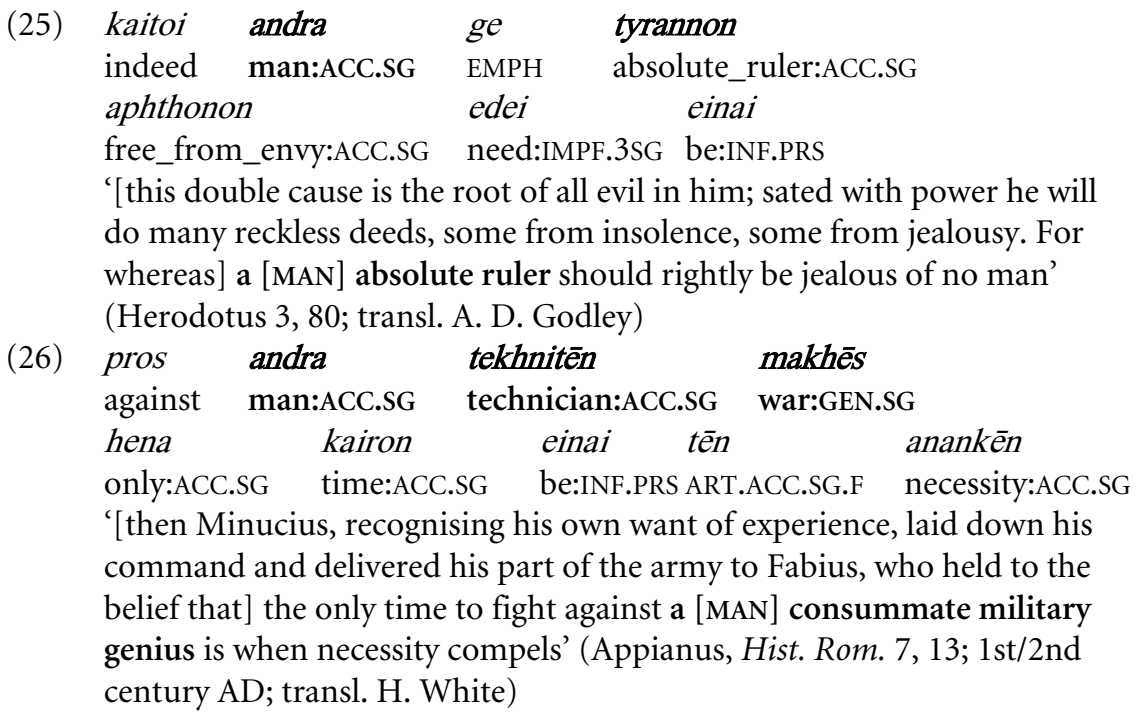

Last, but far from least, the construction in question typically introduces A NEW REFERENT at the beginning of a more or less lengthy story about him. The referent introduced by anêr/anthrōpos + common noun is generally PERSISTENT, i.e. it is likely to appear in subsequent clauses after its first mention. By way of exemplification, consider the following passages. In all of them, the referent introduced by the construction anerranthropos + common noun continues to appear in subsequent portions of the text; for instance, it is anaphorically referred to by means of a demonstrative pronoun in (27) and (28), by means of a definite NP in (29), or simply through verbal agreement in (30). According to Givón (1983), persistence of a referent is indicative of its topical status:

$$
\begin{array}{lllll}
\text { en } & \text { taute } & \text { de } & \text { symmisgousi } & \text { andri } \\
\text { in } & \text { this:DAT.SG.F } & \text { PTCL } & \text { commingle:PRS.3PL } & \text { man:DAT.SG }
\end{array}
$$




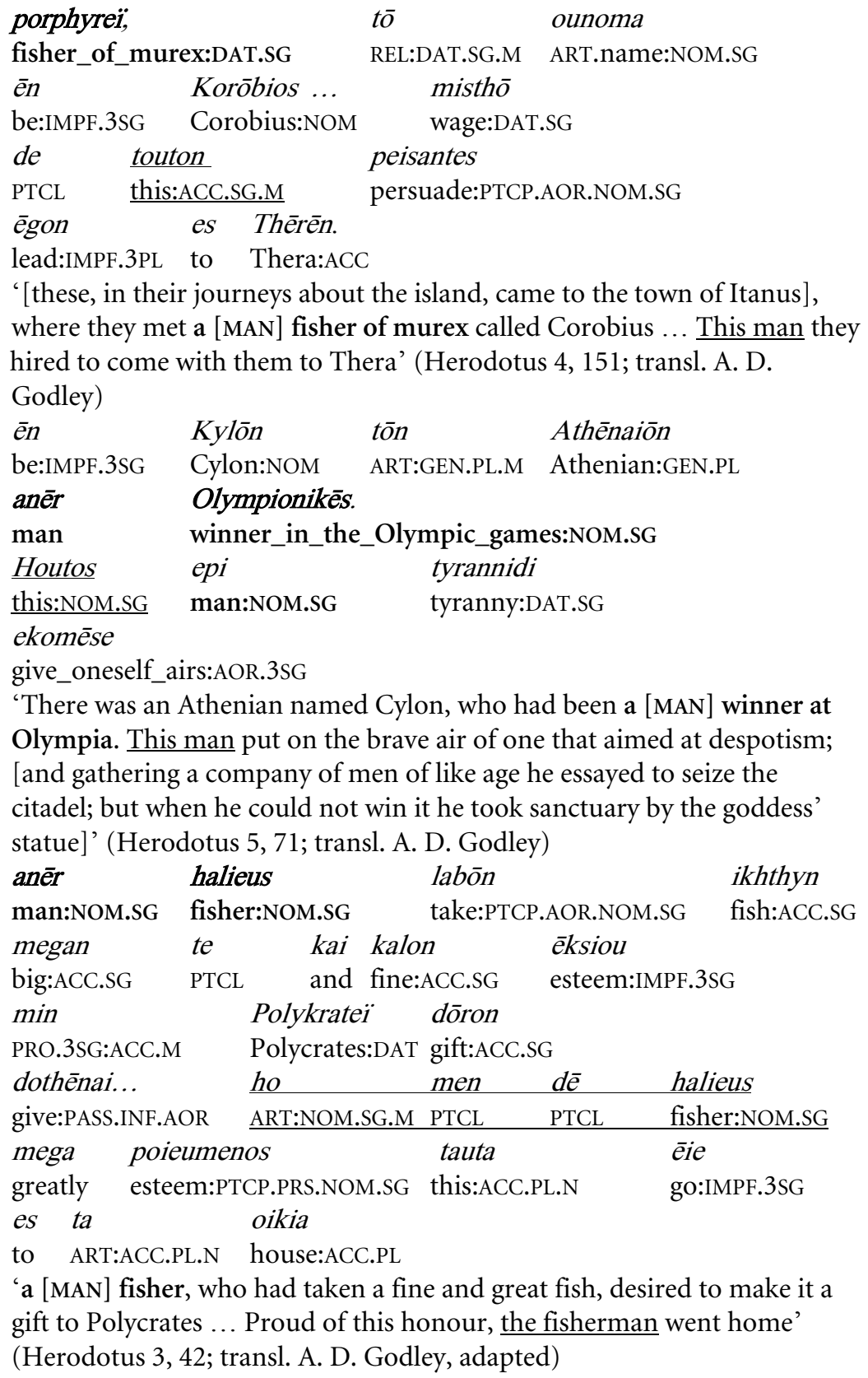


$(30)$

$\begin{array}{llll}\text { ta } & \text { men } & \text { nyn orygmata } & \text { anēr } \\ \text { ART:ACC.PL.N } & \text { PTCL } & \text { now mine:ACC.PL } & \text { man:NOM.SG }\end{array}$

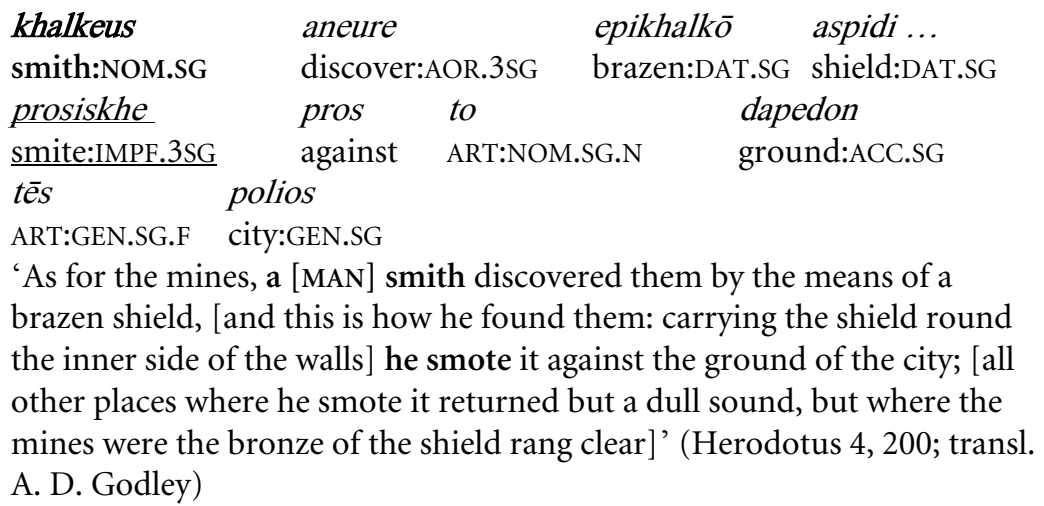

The contrast between anēr Spartiatēs vs. Spartiatēs in examples (16)-(19) above can be at least partly explained in terms of the relative persistence of the referent: while referents introduced by anēr Spartiatēs tend to be quite persistent (they are generally central characters in the narration, and continue to appear after their first mention), referents introduced by Spartiatēs are more ephemeral, and their persistence tends to be quite low. This tendency is indicative of a more topical status of the referents introduced by the construction aner + common noun.

\section{Anēr/anthrōpos + common noun as a classifier construction}

We may now return to the question posed at the beginning of this article, namely whether the construction anerr/anthropos + common noun can be considered as an instance of an emergent classifier construction. Before we can approach this question, we need to take a brief survey of the peculiarities of noun classifiers and classifier constructions within the realm of nominal classification systems, with the aim of assessing the plausibility of an analysis of anēr/anthrōpos + common noun as a classifier construction. This will be done in Section 3.1. In Section 3.2, I will concentrate on the correlation between the use of noun classifiers (and classifier constructions) and the discourse status of classified referents. Besides having a proper classificatory function, noun classifiers are tightly connected to the semantic/pragmatic domain of determination/reference (Croft 1994: 147): they are often 
determiners in function, and are deployed to mark a given discourse status of their referents, although the concrete ways in which they are used with a determiner-like function may be quite divergent across languages. Emergent classification strategies such as classifier constructions (defined as in (34) below) are even more dependent on the discourse status of referents, which appears to be crucial in favouring the pairing of generic and specific nouns. Finally, in Section 3.3 I will review the Greek data in the light of the typological literature on noun classifiers.

\subsection{Noun classifiers between lexicon and grammar}

The nominal classification systems known as "classifiers" include a number of subtypes that can be distinguished by their semantics and their morphosyntactic status. Overall, classifiers can be taken to "occupy the mid point" (Grinevald \& Seifart 2004: 262) between the two types of nominal classification systems found in European languages, the morphosyntactic system of gender (Italian il ragazzo 'the boy' vs. la ragazza 'the girl') and the lexical expression of measure terms and unit counters (a grain of sand, a cup of milk, etc.): classifiers have clearly lexical origin, yet they behave in a more or less syntacticized way; unlike gender they do not usually classify all nouns.

Noun classifiers constitute a type of their own, traditionally lesser-studied than other classifiers (numeral, verbal, and possessive classifiers), although the gap in the comprehension of their functioning has been increasingly filled in recent years (Aikhenvald 2000: 81-97; Grinevald 2000: 65ff, 2002, 2007; Wilkins 2000; Grinevald \& Seifart 2004, among others). The label noun classifier must be understood in opposition to numeral and possessive classifiers, as noun classifiers "commonly stand alone with their referent noun, independent of quantification or possession" (Grinevald 2004: 1019). In languages with a fully-fledged system of noun classifiers, these are items with superordinate semantics which combine with nominals having a more specific meaning. The noun classifier may (but needs not) "resemble" the noun which has been its lexical source, as in the Jakaltek example in (8) above, with the classifier naj < winaj 'man'. ${ }^{11}$ The pairing of a classifier and a specific noun is rather conventionalized, and the classifier typically does not add any information about the semantic nature of the referent which is not

${ }^{11}$ In such cases the term REPEATER is sometimes used in the literature (Grinevald 2007: 100). 
already available in the noun with which it co-occurs (Downing 1986: 348). The specific nouns in (31) and (32), for instance, inherently designate female beings (malin 'Mary', yaburungu 'girl:ERG') and animals (txitam 'pig', gangu:l 'wallaby:ABS'):

(31) Jakaltek (Craig 2002: 265)

$\begin{array}{lllll}\text { xil } \quad \boldsymbol{i} \boldsymbol{X} & \text { malin } & \text { no' } & \text { txitam } \\ \text { saw } & \text { CL.FEMALE } & \text { Mary } & \text { CL.ANIMAL } & \text { pig } \\ \text { 'Mary saw the pig' } & & & \end{array}$

(32) Yidiny (Dixon 1977: 480)

$\begin{array}{llll}\begin{array}{l}\text { bama:l } \\ \text { CL.PERSON:ERG }\end{array} \quad \begin{array}{l}\text { yaburugul } \\ \text { girl:ERG }\end{array} & \begin{array}{l}\text { mina } \\ \text { CL.ANIMAL:ABS }\end{array} & \begin{array}{l}\text { gangu:l } \\ \text { wallaby:ABS }\end{array} \\ \text { Wawa:l } & & & \\ \text { see:PST } & & & \\ \text { 'the girl saw the wallaby' } & & \end{array}$

This feature distinguishes noun classifiers from other, more lexical classification strategies such as CLASS TERMS, exemplified in (33). Class term systems involve a compounding process with various degrees of productivity in which a generic noun (man, tree, berry) is combined with another noun which DOES NOT in itself designate a specific subordinate item within the larger set identified by the generic noun (Grinevald 2002: 261). This compounding process participates "in the lexico-genesis of a language" (Grinevald 2000: 59), and is often in competition with other derivational processes, such as for instance neo-classical suffixation in English: journal-ist, novel-ist, etc. Class terms are typically found in two semantic domains, namely human occupations and the vegetal world, and have in general

${ }^{12}$ Occasionally, noun classifiers may function as "informative" (i.e. properly classificatory) devices providing some kind of unexpected or disambiguating information about their referent. The typical case in which noun classifiers help specify the meaning of the specific noun with which they co-occur is with polysemous nouns, which may combine with different classifiers to yield different meanings, as in the following examples:

(i) Murrinh-Patha (Australian, Daly, Murrinh-Patha; Walsh 1997: 275): nanthi kamarl CL.GENERIC + 'eye' = 'eye'; kura kamarl CL.AQUATIC + 'eye' = 'water-hole'; mi kamarl CL.VEGETABLE + 'eye' = 'seed'

(ii) Minangkabau (Austronesian, Western Malayo-Polynesian, Sundic; Aikhenvald 2000: 84): batang limau CL.TREE + 'lemon' = 'lemon tree'; buah limau CL.FRUIT + 'lemon' = 'lemon fruit' 
limited productivity and a high degree of lexicalization, being restricted to a closed class of nouns or noun roots (Aikhenvald 2000: 86):

(33) a. strawberry, blueberry, raspberry, gooseberry, etc.

b. apple tree, banana tree, orange tree, etc.

c. mailman, policeman, garbage man, etc.

Because of their intermediate position between morphosyntactic and lexical systems of classification, noun classifiers are generally taken to be less grammaticalized than gender and noun class systems. This assumption is grossly incomplete and one-sided, and overshadows the substantial functional similarity between noun class systems as attested e.g. in NigerCongo languages and systems of noun classifiers such as those known from Amazonian languages (Grinevald \& Seifart 2004: 280ff). Moreover, languages with noun classifiers may vary with respect to their degree of grammaticalization. In the literature on noun classifiers various criteria have been proposed to decide to what extent a system of noun classifiers is grammaticalized. The simplest of such criteria is FREQUENCY of occurrence of the classifier + noun pairing (Sands 1995: 270). Languages in which noun classifiers are always or almost always included in a noun phrase are rarer than languages in which the classifier is included only occasionally. Jakaltek and Yidiny are usually mentioned as prototypical instances of languages with a highly conventionalized system of noun classifiers, "in which most nouns in conversation or narrative are preceded by an appropriate classifier" (Sands 1995: 269). The following properties of Jakaltek noun classifiers can be taken as indicative of a system at an advanced stage of grammaticalization (Grinevald 2002: 268): (i) they can function both as determiners of the nouns and as proforms; (ii) they are a frozen closed system used for referential tracking; and (iii) they are phonetically reduced forms of the nouns from which they originate (naj 'CL.HUMAN' < winaj 'man'; no' 'CL.ANIMAL' < noq' 'animal', etc.).

If noun classifiers are used only occasionally, there is usually a great deal of register and speaker variation: noun classifiers may be used rather consistently in formal speech, or in technical ${ }^{13}$ discourse situations, whereas they are omitted in casual/informal speech; as for speaker variation,

\footnotetext{
${ }^{13}$ "Technical" is intended here as including any kind of specialized knowledge of the human and natural world.
} 
proficiency in noun classifiers generally varies from one speaker to another (Aikhenvald 2000: 83).

This cross-linguistic variation has led some authors to introduce the notion of GENERIC-SPECIFIC CONSTRUCTIONS Or CLASSIFIER CONSTRUCTIONS (e.g. Wilkins 2000: 159-160). Classifier constructions are weakly grammaticalized (i.e. occasional, unsystematic) pairings of generic and specific nouns representing the initial stage in the grammaticalization path leading from generic nouns to noun classifiers. In what follows, the notion of classifier construction, defined as in (34), will be adopted and applied to the Greek data, as it does not commit us to any particular claim concerning the existence of noun classifiers in Ancient Greek:

(34) A classifier construction is a construction in which a free-form lexeme with superordinate semantics precedes (or follows) a more specific noun, without any implications as to the degree of obligatoriness/ conventionalization of the construction itself. Such a construction is preferentially associated with an identifiable set of discourse situations in which it contributes its particular meaning. ${ }^{14}$

\subsection{Noun classifiers as determiners}

Though mostly uninformative, noun classifiers are not redundant. Besides classifying nouns, their main semantic/pragmatic function is determination/ reference, i.e. they convey information about the discourse status of their referents (Croft 1994: 147ff). The dependence of noun classifiers on discourse conditions (their "determiner-like role", Grinevald 2002: 266) has been repeatedly hinted at in the literature. In Jakaltek, for instance, noun classifiers function as markers of referentiality, as shown e.g. by the contrast between (35) and (36), or serve the same function as anaphoric pronouns, as in (37).

\footnotetext{
${ }^{14}$ This definition, based on Wilkins (2000: 159ff), adheres to the Construction Grammar claim that constructions have meaning (Goldberg 1995), with the proviso that "meaning" should be understood as including all of the conventionalized linguistic knowledge connected to a given grammatical entity, "which may include not only properties of the situation described by the utterance but also properties of the discourse in which the utterance is found" (Croft 2001: 19).
} 
(35) Jakaltek (Grinevald 2002: 266)

sonlom naj xuwan

musician CL.MALE John

'John is a musician'

(36)

*naj sonlom naj xuwan

CL.MALE musician CL.MALE John

'(man) John is a ( ${ }^{*}$ man) musician'

$\begin{array}{lll}\text { xil } & \text { ix } & \text { naj/no'/te' } \\ \text { saw } & \text { CL.FEMALE } & \text { CL.MAN/CL.ANIMAL/CL.PLANT } \\ \text { 'she (woman) saw him (man)/it (animal)/it (plant)' }\end{array}$

Referential nouns in Jakaltek are usually introduced by the indefinite marker or without a classifier. Noun classifiers are generally found with second mentions of referents: compare the use of the noun classifier for animals in (39) with the simple NP txitam 'pigs' in (38) (the two examples are excerpts from the same narration). The only time a classifier can appear with an indefinite NP is "for a special effect of conveying an important new protagonist" (Wilkins 2000: 157, quoting a personal communication from C. Grinevald).

(38) Jakaltek (Craig 1986b: 269)

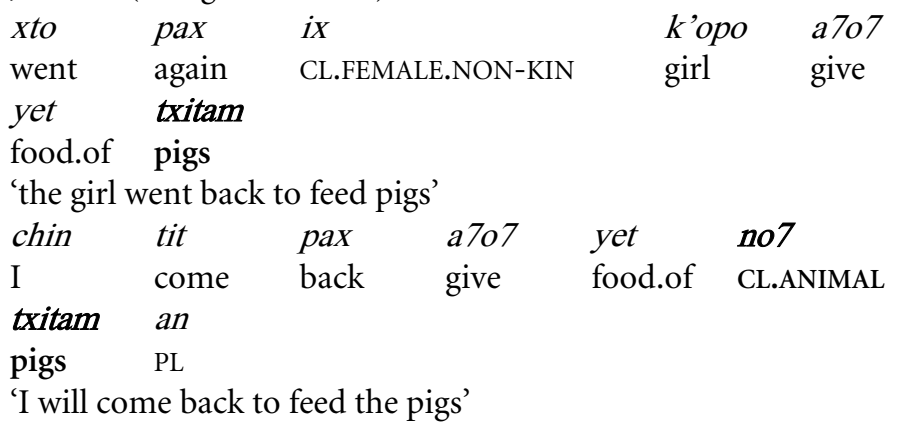

In some languages we find the opposite pattern. In Mandarin Chinese, for instance, there is a distinction between the general classifier $g e$ and specific classifiers. ${ }^{15}$ The latter typically mark the first mention of a new referent,

\footnotetext{
${ }^{15}$ General classifiers are opposed to specific classifiers according to the scope of the class they define and their lexical origin (Grinevald 2007: 100-101). Specific classifiers head classes of elements clustered around prototypical exemplars, and
} 
whereas, "once reference is established, subsequent mentions take the general classifier or constructions where no classifier is required" (Erbaugh 1986: 408):

(40) Mandarin (Sino-Tibetan, Chinese; Erbaugh 1986: 408)

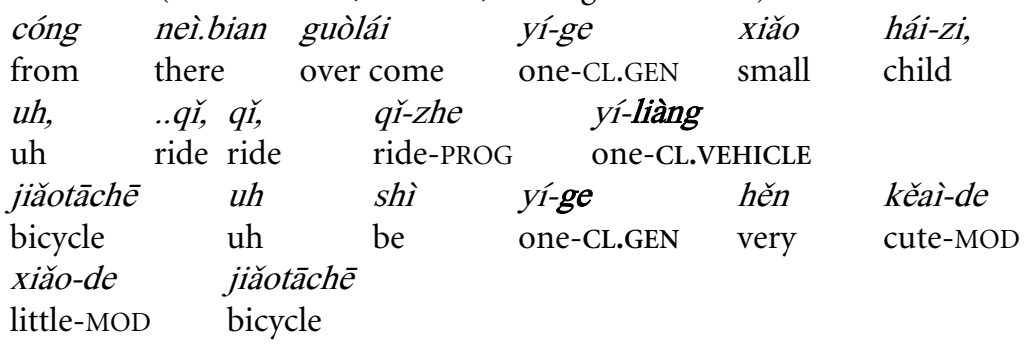

'from over there comes a child, uh, ride, ride, riding a bycicle, uh, it is a very cute little bicycle'

The use of classifiers to convey information about the discourse status of referents is perhaps more evident in languages with less developed noun classification systems. In emerging systems, the discourse status of referents appears to be crucial in favouring the occasional pairing of generic and specific nouns. According to Aikhenvald (2000: 333), "all non-obligatory classifier systems have some discourse-pragmatic function [whereas] obligatory classifier systems tend to display similar properties, but to a lesser extent".

The discourse-pragmatic functions of classifier constructions are quite divergent across languages. Sometimes the generic-specific construction must be used when a new referent is introduced, whereas subsequent mentions of the same referent use only the generic noun. In Minangkabau, for instance, the specific noun is "often omitted if the referent has already been established in discourse or is known from the context" (Aikhenvald 2000: 322); compare (41), where a new referent is introduced, with (42), where the referent is given.

their lexical source is generally (although not necessarily) transparent, whereas general classifiers head large heterogeneous classes and have opaque semantics. 
(41) Minangkabau (Austronesian, Western Malayo-Polynesian, Sundic; Aikhenvald 2000: 322)

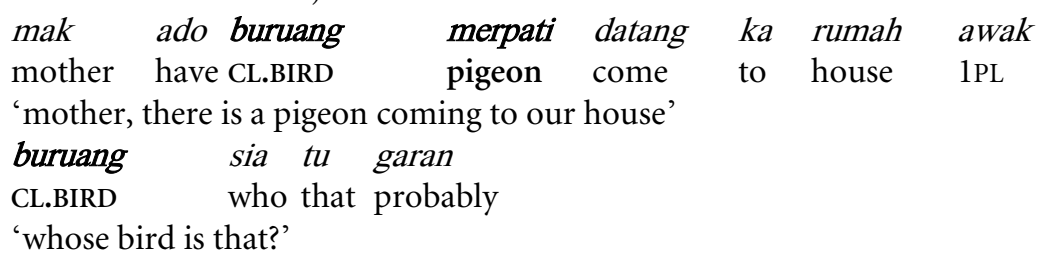

In Kugu-Nganhcara the generic noun is always present when vocabulary is elicited, or with first mentions of referents, but it can be omitted when the referent is already established in discourse (Smith \& Johnson 2000: 446). In (43), an excerpt from an oral narration, the two characters (two personified birds: a curlew and a crow) are introduced by means of a combination of the generic noun for animals (minha) and a more specific noun; subsequently, they are referred to by means of independent pronouns, simple (i.e. unclassified) NPs, and verbal agreement:

(43) Kugu-Nganhcara (Australian, Pama-Nyungan; Smith \& Johnson 2000: 463)

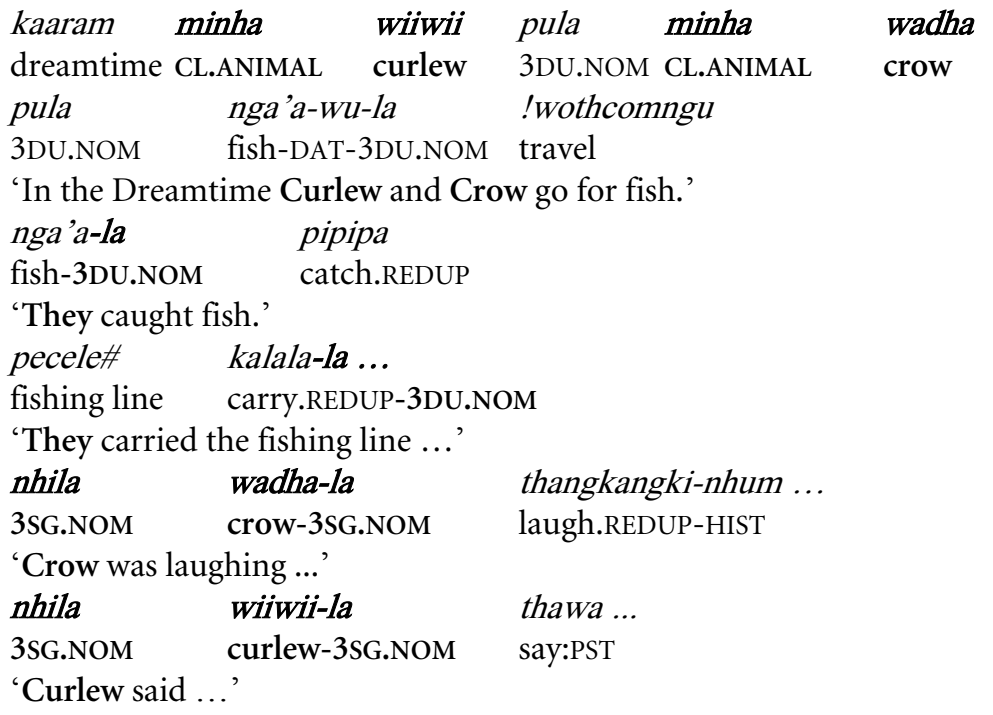

Hopper (1986) lists a number of parameters that are conducive to the use of generic nouns in written Malay. In this language, only a subset of indefinite 
nouns may combine with generic nouns forming a classifier construction, whereas definite nouns are virtually never classified. A prototypical classified noun has specific reference, and the clause in which it appears depicts a past/factual state of affairs (whereas in clauses expressing future/non-factual states of affairs nouns are generally unclassified). Generic nouns are frequently found in presentative constructions, i.e. constructions introducing a new participant into discourse: the new referent introduced by the classified noun is also rather persistent, that is, it is expected to be spoken about later. (44) is a typical example of the use of classifier constructions in Malay: the clause depicts a past/factual state of affairs; the classified noun refers to a major character that is being introduced in the narration for the first time, and that will be referred back to in subsequent discourse. ${ }^{16}$

(44) Malay (Austronesian, Western Malayo-Polynesian, Sundic; Hopper 1986: 314)

maka ku-dapati ada di-tengah rumah ada sa-orang orang Pelekat yang bernama Abdul Satar tengah makan

'and I discovered that there was $\mathbf{a}<\mathrm{CL}>$ man from Pelekat by the name of Abdul Satar in the middle of the room engaged in eating'

The patterns discussed above nicely show that the main function of noun classifiers falls within the functional domain of reference/individuation,

${ }^{16}$ According to Wilkins (2000: 157ff), classifier constructions in Arrernte (Australian, Pama-Nyungan) appear to be insensitive to the discourse status of referents. Referents of generic-specific constructions in this language are often non-specific and the construction itself is not used as a means for introducing important new protagonists. Instead, its distribution in discourse appears to be connected with the semantic and syntactic roles of referents:

the simple generic NP and the NP headed by the generic-specific construction occurred exclusively in accusative or dative case. Crudely speaking, the referents of these phrases were always having something done to them. By contrast, when the NP was headed by just the specific noun, there were $\ldots .5$ nominative uses and 2 ergative uses ... Again, crudely speaking, the referents of these phrases are commonly doing something (Wilkins 2000: 173).

Grinevald (2002: 271) connects the limited discourse anaphoric use of Arrernte generic-specific constructions to a specific typological feature of this language, namely the presence of third person independent pronouns, whereas in Jakaltek the system of noun classifiers has developed in the context of a language without $3 \mathrm{rd}$ person independent pronouns. 
rather than classification as such. The individualizing function of noun classifiers is of course strictly connected to their classifying function, classification being "a basic prerequisite to identification" (Croft 1994: 161). This function of noun classifiers also explains why they profile the NATURE/ESSENCE of the noun they co-occur with, whereas in other types of classifiers other semantic dimensions are more relevant (Grinevald 2002: 263). Possessive classifiers, for instance, that is, classifiers that co-occur with the possessed noun in a possessive construction, characterize the noun mainly in terms of its function or potential use, as in (45) and (46). Numeral classifiers, that is, classifiers appearing contiguous to numerals in numeral expressions, generally profile the shape or size of the noun they co-occur with, as in (47). ${ }^{17}$

(45) Macushi (Cariban; Aikhenvald 2000: 129)

u-yekkari ma'pîya

1SG-POSS.CL.FRUIT_FOOD papaya

'my papaya' (= the papaya that I'm going to eat)

(46) Ulithian (Austronesian, Eastern Malayo-Polynesian, Oceanic; Croft 1994:

154)

lawu-yi yixi

CL-my fish

'my fish, that I'm keeping'

xala-yi yixi

CL-my fish

'my cooked-fish food'

xocaa-yi yixi

CL-my fish

'my raw-fish food'

(47) Pohnpeian (Austronesian, Eastern Malayo-Polynesian, Oceanic;

Grinevald 2002: 262)

tuhke rioapwoat

tree 2+NUM.CL.LONG

'two trees'

\footnotetext{
${ }^{17}$ As Grinevald (2007: 98) notes, however, these correlations between classifier type and their prototypical semantic profile "work best in languages with co-occurring classifier systems", whereas "the correlation is less strong in the case of large numeral classifiers, particularly when they are the only classifier system of a language, in that all three semantic fields [i.e. nature/essence, function/use, and size/shape, AS] may well be represented, in varying proportion".
} 
A final remark is necessary before moving on to the analysis of the Greek data. The size of inventories of noun classifiers may range from a very limited set to several hundreds of classifiers (Aikhenvald 2000: 84ff). The semantic distinctions employed in systems of noun classifiers, however, are usually not random, but comply with the hierarchy in (48) (based on Croft 1994: 148), which has both a synchronic and a diachronic value.

(48) Human/animate entities (male/female) $>$ higher animals $>$ lower animals (insects, etc.) / natural objects (plants, etc.) $>$ artifacts

Animacy is the crucial dimension in this hierarchy. Synchronically, this means that (i) the most important divisions in noun classifiers are those opposing human/animate beings to (higher) animals and to nonhuman/inanimate beings, and that (ii) limited systems of noun classifiers normally have at least one classifier for humans. If a language has a richer set of noun classifiers, there can be classifiers for male and female human entities (i.e. distinctions based on sex), and for non-human and inanimate entities. The semantic distinctions among non-human and inanimate entities are generally based on the nature of the referent (trees, birds, insects, plants, etc.) rather than its function or shape. Artifacts come next in this hierarchy of distinctions. If there are distinctions in the class of artifacts, they have to do with major artifact classes such as furniture, weapons, vehicles, clothing, etc. (Croft 1994: 161-162). From a diachronic point of view, the hierarchy captures the fact that noun classifiers are grammaticalized more easily for entities at the top of the hierarchy.

The functional motivation for this hierarchy has to do with the fact that "people talk about people more than about anything else" (Croft 1994: 162), and the primary distinction among human beings is sex. Higher mammals or animals come next, but their position in noun classifier systems may also mirror the culture-specific economic or social importance of these items, or may be influenced by certain discourse situations, such as technical discourse, which favour the adoption of noun classifiers for these entities.

\subsection{An embryonic system of noun classification in Greek: revisiting the data}

In the light of the typological survey conducted in the two previous sections, there appear to be good reasons to revisit the Greek data discussed in Section 
2 and to address the question of whether they lend themselves to an interpretation in terms of an embryonic system of noun classification. It is to this task that we now turn.

The fact that the construction aner/anthroppos + common noun is found in a subset of the contexts in which languages with indefinite articles employ these is suggestive of the determiner-like function of aner and anthroppos in the construction under discussion. Furthermore, the extremely optional character of this construction, already acknowledged by Kühner (1898), is indicative of its being an "incipient" strategy within the functional domain of reference/individuation: incipient constructions are optional in that they may but need not be used, and the grammatical meaning expressed by the construction in question is not obligatorily marked (Heine \& Kuteva 2005: 71ff). In other words, absence of the classifier construction does not necessarily imply absence of the "meaning" associated with it.

As an incipient strategy, this construction does not cover all indefinite contexts, but only a subset of them. In particular, the construction is associated with the following types of referents: (i) pragmatically referential indefinite arguments, e.g. main characters that remain salient and are talked about in subsequent discourse, as in (27)-(30); and (ii) indefinite/generic arguments under the scope of non-assertive operators or in gnomic contexts, as in (23)-(26). Significantly, the discourse contexts covered by this construction correspond to the contexts in which the numeral one grammaticalizes more easily into an indefinite article, as shown in Figure 2 (see Givón 1981; Weiss 2004): ${ }^{18}$ incipient indefinite articles are generally triggered by the degree of topicality of their referent, i.e. they introduce "new and long-lived referents" (Weiss 2004: 146), whereas grammaticalized indefinite articles "may establish any new referent, including the most ephemeral one" (ibidem).

\footnotetext{
${ }^{18}$ Weiss (2004: 156) posits a slightly different grammaticalization channel leading from the numeral one to the indefinite article, based on Macedonian data: specificity of the referent is no doubt one of the factors fostering the grammaticalization of the numeral eden 'one' as an indefinite article, yet the decisive factor in the development of the rightmost uses in Figure 2 turns out to be the presence of "further specification of the NP by attributive modifiers or relative clauses" (Weiss 2004: 157), irrespective of the specificity parameter.
} 


\begin{tabular}{|c|c|c|c|c|c|c|}
\hline $\begin{array}{l}{[\text { Pragmatically] }} \\
\text { referential indefinite } \\
\text { arguments; exx. (27)- } \\
(30)\end{array}$ & $>$ & $\begin{array}{l}\text { Non-referential } \\
\text { indefinite } \\
\text { arguments under } \\
\text { non-assertive } \\
\text { operators; exx. } \\
(23)-(24)\end{array}$ & $>$ & $\begin{array}{l}\text { Generic } \\
\text { expressions; exx. } \\
(25)-(26)\end{array}$ & $>$ & $\begin{array}{l}\text { Predicative } \\
\text { nominals (e.g. } \\
\text { John is a } \\
\text { teacher) }\end{array}$ \\
\hline
\end{tabular}

Figure 2. The grammaticalization path of one as an indefinite article (based on Givón 1981: 49 and Weiss 2004: 156, adapted; the contexts on the right admit the use of one as indefinite article less easily - and only at an advanced stage)

As far as chronology is concerned, the construction is already wellestablished in the classical prose of the 5th century $\mathrm{BC}$, and continues to be particularly vital in Hellenistic Greek. A precise sociolinguistic (or stylistic) characterization of this construction is beyond the scope of this paper. Although this construction enjoys some currency in poetry, most attestations come from narrative prose. In terms of absolute frequency, the number of attestations tends to increase in Koine Greek, where the construction is found both in authors whose style appears to be heavily modelled on classical prose such as Plutarch (49) or Pausanias (ex. (13) above), and in more popular genres such as novels and fables, exemplified in (50)-(51):

\begin{tabular}{llcc} 
epanelthonti & \multicolumn{1}{c}{ de } & dolon & mēkhanasthai \\
return:PTCP.AOR.DAT.SG PTCL & plot:ACC.SG contrive:INF.PRS \\
synōmotas & andras & hebdomēkonta \\
conspirator:ACC.PL & man:ACC.SG & seventy \\
kai $\quad$ dyo & pepoiēmenon & \\
and & two & make:PTCP.PF.ACC.SG
\end{tabular}

'[during his absence the tradition is that Typhon attempted nothing revolutionary because Isis, who was in control, was vigilant and alert]; but when he returned home Typhon contrived a treacherous plot against him and formed a group of seventy-two [MEN] conspirators. [He had also the co-operation of a queen from Ethiopia who was there at the time and whose name they report as Aso]' (Plutarchus, De Iside et Osiride 356, B, 49, 2nd century AD; transl. B. Perrin, adapted)

$\begin{array}{lll}\text { anēr } & \text { geōrgos } & \text { mellōn } \\ \text { man:NOM.SG } & \text { farmer:NOM.SG } & \text { be_on_the_point:PTCP.PRS.NOM.SG } \\ \text { teleutan } & \text { kai boulomenos } & \text { tous } \\ \text { die:INF.PRS } & \text { and wish:PTCP.PRS.NOM.SG } & \text { ART:ACC.PL.M }\end{array}$




$\begin{array}{llrl}\text { autou } & \text { paidas } & \text { empeirous } & \text { einai } \\ \text { PRO.3SG:GEN } & \text { child:ACC.PL } & \text { expert:ACC.PL be:INF.PRS } \\ \text { tēs } & \text { geōrgias } & \text { metakalesamenos } \\ \text { ART:GEN.SG.F } & \text { agriculture:GEN.SG } & \text { call:PTCP.AOR.NOM.SG } \\ \text { autous } & \text { ephē } & & \\ \text { PRO.3PL:ACC } & \text { say:IMPF.3SG } & \end{array}$

'a [MAN] farmer being on the point of death, and wishing his sons to become expert in farming, called them to his bedside, and said: ["My sons, there is a treasure hidden in one of my vineyards"]' (Aesopus, Fabulae 42,1 ; 1st-2nd century AD) ${ }^{19}$
ou gar
perieides
andra
NEG indeed
allow:AOR.2SG
man:ACC.SG

idiōtēn

epibouleuthenta

private_citizen:ACC.SG ruin:PASS.PTCP.ACC.SG

hypo hēgemonos

by governor:GEN.SG

'[Dionysius opened his statement as follows: "Your Majesty, I thank you for the regard you pay to me, my wife's chastity, and the institution of marriage.] You have not allowed a [MAN] private citizen to be ruined by a governor's intrigue [but have summoned him here, so that by punishing his immoral and vicious behavior towards me you may stop it in other cases"]' (Chariton, De Chaerea et Callirhoe 5, 6, 1; 1st century AD; transl. G. P. Goold)

If we are willing to recognize a popular, everyday component in Koine Greek, the extraordinary vitality of this construction in this variety leads us to assume that the construction emerged as a popular feature, and its sporadic occurrence in the classical prose overshadows the fact that in everyday language it was possibly more widespread.

Also worthy of mention is that the construction in question is not the only classifier construction attested in Ancient Greek. Although there are fewer examples, the nouns gynē 'woman', and ornis 'bird', also appear in association with more specific nouns in roughly the same discourse environments as anēr and anthrōpos.

19 It is interesting, too, that another version of this fable uses the indefinite adjective/pronoun tis in this passage:

(iii) geōrgos tis mellōn katalyein ton bion ...

'a farmer being on the point of death ...' 
(52)

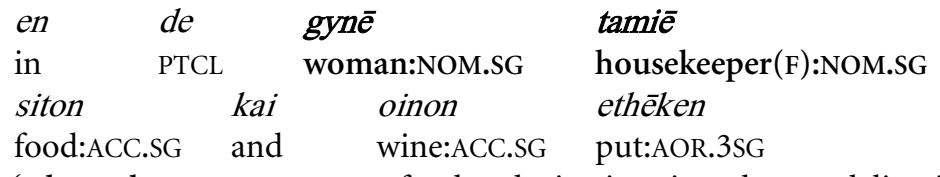

'a housekeeper woman put food and wine into it and some delicacies, [the kind of things that kings, cherished by the gods, eat]' (Od. 3, 479-480; 8th century BC; transl. R. D. Dawe)

\begin{tabular}{|c|c|c|c|}
\hline & & $\begin{array}{l}\text { gynē } \\
\text { woman:NOM.SG }\end{array}$ & $\begin{array}{l}\text { hetaira, } \\
\text { courtesan }(\mathrm{F}) \cdot \mathrm{NOM} S \mathrm{~S}\end{array}$ \\
\hline Tais & onoma, & $h \bar{e} S$ & Arkhias \\
\hline & name:ACC.SC & REL:GEN.SG.F & Archias:NOM \\
\hline Luri & ostin & ho & $d^{\prime}$ \\
\hline
\end{tabular}

keeper:NOM.SG be:PRS.3SG ART:NOM.SG.M PTCL

Hymenaios epitēdeios, ho

Hymenaeus:NOM.SG intimate:NOM.SG ART:NOM.SG.M

Philōnidēs d' eran phèsin

Philonides:NOM PTCL love:INF.PRS say:PRS.3SG

'there's a courtesan, Nais by name, whose keeper is Archias, whose

intimate is Hymenaeus, and whom Philonides admits he loves' (Lysias, Fragmenta 363; 5th century BC)

(54) kan Dii thye e basilei

and.if Zeus:DAT sacrifice:SBJV.PRS.3SG king:DAT.SG

krion, basileus est'

ram:ACC.SG king:NOM.SG be:PRS.3SG

orkhilos ornis

wren:NOM.SG bird:NOM.SG

'while if one is sacrificing a ram to Zeus the King, the wren is the king, [and to him, in advance of Zeus himself, an uncastrated gnat must be immolated]' (Aristophanes, Aves 568-569; 5th century BC; transl. A. H. Sommerstein, adapted)

(55) ei de tynkhanei

if PTCL happen:PRS.3SG INDEF_PRO:NOM.SG be:PTCP.PRS.NOM.SG

Phryks mèden hètton Spintharou,

Phrygian:NOM.SG nothing less Spintharus:GEN

phrygilos ornis houtos

frigate_bird:NOM.SG bird:NOM.SG this:NOM.SG

estai, tou Philemonos genous.

be:FUT.3SG ART:GEN.SG.N Philemon:GEN stock:GEN.SG

'and if someone happens to be a Phrygian - as thoroughly Phrygian as Spintharus - he'll be a frigate-bird of Philemon's stock' (Aristophanes, Aves 762-763; transl. A. H. Sommerstein) 
(56)

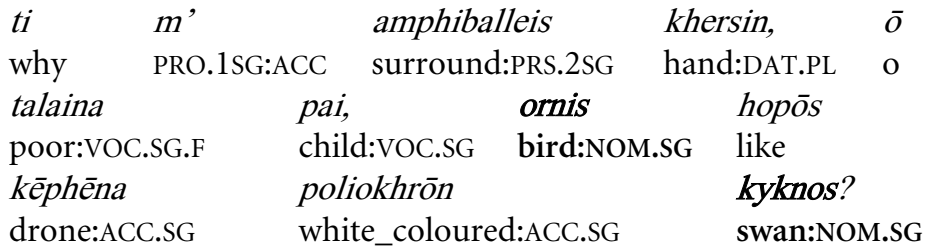

'why do you put your arms around me, $\mathrm{O}$ wretched child, like a swan (does to) its white-coloured drone (of a parent)?' (Euripides, Bacchae 1364-1365; 5th century BC; transl. R. Seaford, adapted)

Finally, somewhat problematic for the present analysis of anēr/anthrōpos as (incipient) noun classifiers in classifier constructions are passages such as (20)-(22), in which the two terms co-occur with numeral expressions. Numeral expressions are the discourse environment par excellence in which numeral classifiers are used. Noun classifiers are deemed to be semantically rather different from numeral classifiers: whereas the former profile the nature/essence of the classified item, the latter generally profile its shape or dimensionality, as in (47) above. ${ }^{20}$ Being generally limited to enumerations or quantified expressions involving quantifiers such as English some and many, the primary function of numeral classifiers is enumeration/quantification rather than reference/determination (Croft 1994: 151ff). It has been convincingly argued, however, that even the use of numeral classifiers has an individualizing function and may be heavily influenced by the discourse status of the classified item. In languages with numeral classifiers they are used more often (if not exclusively) with small numbers because "the members which compose the grouping referred to are thought of as distinct individuals, not just mere category tokens which together amount to the sum denoted" (Downing 1986: 354). In Malay, for instance, where the same terms are used as both noun and numeral classifiers, "it is when the number is being insisted upon, and hence something is being made of the noun phrase in the discourse, that the classifier is used" (Hopper 1986: 318).

\footnotetext{
${ }^{20}$ The distinction between noun classifiers and numeral classifiers with respect to what they profile is more evident with inanimate nouns. Both noun classifier and numeral classifier systems distinguish an animate or human class, and further distinctions within the set of human/animate entities are based primarily on sex. Numeral classifiers for inanimate entities, unlike noun classifiers for inanimates, make further distinctions based on shape or dimensionality.
} 
These facts show that the functional dimension of determination/ reference is relevant also to numeral classifiers. The distinction between the two types of classifiers cannot be considered as devoid of any theoretical significance, because there are languages in which two clearly differentiated sets of noun and numeral classifiers co-occur (Grinevald 2002: 263). However, the (partial) functional overlap between the two types accounts for why in Malay and other languages the same classifiers can be used in both enumerations, as in (57), and non-enumerated contexts, as in (58), and can be also invoked as an explanation for the use of anēr and anthrōpos in numeral expressions.

(57) Malay (Hopper 1986: 310, 320)

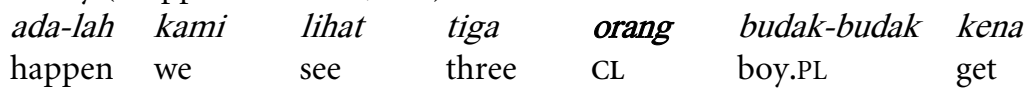

hukum

punishment

'we happened to see three $<\mathrm{CL}>$ boys being punished'

(58) Arakian maka pada suatu hari datang sa-orang nakhoda menchari bapa-ku dirumah

'now one day there came a $<\mathrm{Cl}>$ sea-captain to look for my father at home'

\section{Concluding remarks}

Classifier constructions can be thought of as an intermediate stage on the grammaticalization path leading from generic superordinate nouns to noun classifiers, which may be represented as in (59):

(59) (a) Generic superordinate noun $>$ (b) Generic noun + specific noun in a classifier construction $>$ (c) Noun classifier

The use of anēr/anthrōpos, gynē and ornis has never reached stage (c). More importantly, in Medieval Greek the three terms stop being used even in classifier constructions. The decline and eventual loss of a grammaticalized stage on a grammaticalization path has been called RETRACTION by Haspelmath (2004: 33ff). Retraction may have several motivations. A grammaticalization chain may retract because it started in a replica language 
simply as the result of language contact. ${ }^{21}$ In other cases, retraction may be triggered by a process of polarization between two constructions originating from two different grammaticalization processes and concurring with one another within the same functional domain: in such a scenario, the contexts of use of the two constructions may overlap partially or totally in the beginning, but then one construction takes over and the other one ends up being associated with only a subset of the contexts in which it could originally appear (see, for such a case in the history of Italian, Sansò to appear).

The retraction of the classifier constructions in Greek may have been fostered by the contemporary emergence of a concurrent strategy within the functional domain of determination, namely the use of the numeral meaning 'one', heis, as an indefinite article. Heis starts appearing with an "individualizing" function ("isolierte Individualisierung", Kuhlmann: 1999: 82) in the New Testament, and becomes particularly widespread in Medieval Greek. Unlike the four terms appearing in classifier constructions, which are limited to a subset of possible referents comprising men, women and birds, heis can be used with virtually any kind of referent. This favourable distribution of heis cannot account in any simplistic way for WHY the classifier constructions described above did not eventually survive in Medieval Greek, because languages with both indefinite articles and noun classifiers are possible, e.g. Jakaltek. It is a fact, however, that both strategies concur within the same functional domain, and that many languages with noun classifiers DO NOT have indefinite articles. When noun classifiers arise in the context of a language with indefinite articles, they are normally not used as markers of indefinite referents but may develop other functions within the same domain of reference/determination, e.g. they may come to be deployed as anaphoric strategies, as in Jakaltek; cf. example (37) above.

Thus, the answer to why the classifier constructions of Ancient Greek have not survived can be only tentative. It should be borne in mind, however, that the available typological evidence on noun classifiers suggests that it is "their very nature as intermediate systems between lexicon and grammar" (Grinevald 2002: 265) that makes them "fluid" elements in the

${ }^{21}$ This is the case of the impersonal/indefinite uses of uomo 'man' in early ItaloRomance, which originated from contact with French and never became an indigenous trait in Italo-Romance. These uses started to decline coinciding with the decline of French influence on Italian vernaculars (Giacalone Ramat \& Sansò 2007b). 
grammar of a language, characterized by great variation and particularly likely to undergo decay and loss.

\section{Abbreviations}

$1=1$ st person; $2=2$ nd person; $3=3$ rd person; $\mathrm{ABS}=$ absolutive; $\mathrm{ACC}=$ accusative; $\mathrm{AOR}=$ aorist; $\mathrm{ART}=($ definite $)$ article; $\mathrm{CL}=$ classifier; CL.GEN $=$ general classifier; CL.LONG $=$ classifier for elongated objects; COMP $=$ complementizer; $\mathrm{DAT}=$ dative; $\mathrm{DU}$ = dual; $\mathrm{EMPH}=$ emphatic particle; $\mathrm{ERG}=$ ergative; $\mathrm{F}=$ feminine; $\mathrm{FUT}=$ future; $\mathrm{GEN}=$ genitive; HIST = historic; IMP = imperative; $\mathrm{INDEF}_{-} \mathrm{ADJ}=$ indefinite adjective; INDEF_PRO $=$ indefinite pronoun; $\mathrm{IMPF}=$ imperfect; $\mathrm{INF}=$ infinitive; $\mathrm{MOD}=$ modifier; $\mathrm{N}=$ neuter; $\mathrm{NEG}=$ negation; $\mathrm{NOM}=$ nominative; $\mathrm{NUM}=$ numeral; $\mathrm{OPT}=$ optative; $\mathrm{PASS}=$ passive $; \mathrm{PF}=$ perfect $; \mathrm{PL}=$ plural; $\mathrm{POSS}=$ possessive $; \mathrm{PRO}=$ pronoun; $\mathrm{PROG}=$ progressive; $\mathrm{PRS}=$ present; $\mathrm{PST}=$ past; $\mathrm{PTCL}=$ particle; $\mathrm{PTCP}=$ participle; REDUP $=$ reduplicated; $\mathrm{REL}=$ relative pronoun; $\mathrm{SBJV}=$ subjunctive; $\mathrm{SG}=$ singular; $\mathrm{VOC}=$ vocative.

\section{References}

Aikhenvald, Alexandra Y. 2000. Classifiers. A typology of noun categorization devices. Oxford: Oxford University Press.

Black, Matthew. 1967 [1946]. An Aramaic approach to the Gospels and Acts. Oxford: Clarendon.

Blass, Friedrich \& Albert Debrunner. 1961. A Greek grammar of the New Testament and other early Christian literature. Chicago: University of Chicago Press. [English translation of F. Blass \& A. Debrunner. 1931. Grammatik des neutestamentlichen Griechisch. Göttingen: Vandenhoeck \& Ruprecht.]

Bonfante, Giuliano. 1980. The origin of the type French on dit, German man sagt, etc. Word 31: 69-71.

Bubenik, Vit. 1989. Hellenistic and Roman Greece as a sociolinguistic area. Amsterdam: John Benjamins.

Craig, Colette, ed. 1986a. Noun classes and categorization. Amsterdam: John Benjamins.

Craig, Colette. 1986b. Jacaltec noun classifiers: a study in language and culture. In Craig, ed. 295-363.

Croft, William. 1994. Semantic universals in classifier systems. Word 45: 145-171.

Croft, William. 2001. Radical Construction Grammar. Oxford: Oxford University Press. 
Danker, Frederick William, ed. 2000. A Greek-English lexicon of the New Testament and other Early Christian literature. 3rd edition. Chicago: University of Chicago Press.

Dixon, Robert M. W. 1977. A grammar of Yidin. Cambridge: Cambridge University Press.

Dixon, Robert M. W. 1982. Where have all the adjectives gone? and other essays in semantics and syntax. Berlin: Mouton de Gruyter.

Downing, Pamela. 1986. The anaphoric use of classifiers in Japanese. In Craig, ed. 345-375.

Erbaugh, Mary S. 1986. Taking stock: the development of Chinese noun classifiers historically and in young children. In Craig, ed. 399-436.

Gehman, Henry S. 1951. The Hebraic character of Septuaginta Greek. Vetus Testamentum 1: 81-90.

Giacalone Ramat, Anna \& Andrea Sansò. 2007a. The spread and decline of indefinite man-constructions in European languages: an areal perspective. In Paolo Ramat \& Elisa Roma, eds. Europe and the Mediterranean as linguistic areas: convergencies from a historical and typological perspective. Amsterdam: John Benjamins, 95-131.

Giacalone Ramat, Anna \& Andrea Sansò. 2007b. The indefinite usage of uomo, 'man', in early Italo-Romance. Grammaticalization and areality. Archivio Glottologico Italiano XCII (I): 65-111.

Giacalone Ramat, Anna \& Andrea Sansò. To appear. L'emploi indéfini de homo en latin tardif. Aux origines d'un «européanisme». In Aurelie André, ed. La quantification en latin. Actes $d u$ colloque $d u$ centre Alfred Ernout. Paris: L'Harmattan.

Givón, Talmy. 1981. On the development of the numeral 'one' as an indefinite marker. Folia Linguistica Historica 2: 35-53.

Givón, Talmy. 1983. Topic continuity in discourse: an introduction. In Talmy Givón, ed. Topic continuity in discourse: a quantitative cross-language study. Amsterdam: John Benjamins, 1-41.

Givón, Talmy. 1984. Syntax. A functional-typological introduction. Vol. I. Amsterdam: John Benjamins.

Goldberg, Adele E. 1995. Constructions. A Construction Grammar approach to argument structure. Chicago: University of Chicago Press.

Grinevald, Colette. 2000. A morphosyntactic typology of classifiers. In Senft, ed. 5092.

Grinevald, Colette. 2002. Making sense of nominal classification systems. Noun classifiers and the grammaticalization variable. In Ilse Wischer \& Gabriele Diewald, eds. New reflections on grammaticalization. Amsterdam: John Benjamins, 259-275. 
Grinevald, Colette. 2004. Classifiers. In Geert Booij, Christian Lehmann, Joachim Mugdan \& Stavros Skopeteas, eds. Morphology. An international handbook on inflection and word-formation. Berlin: Mouton de Gruyter, 1016-1031.

Grinevald, Colette. 2007. The linguistic categorization of spatial entities. Classifiers and other nominal classification systems. In Michel Aurnague, Maya Hickmann \& Laure Vieu, eds. The categorization of spatial entities in language and cognition. Amsterdam: John Benjamins, 93-121.

Grinevald, Colette \& Frank Seifart. 2004. Noun classes in African and Amazonian languages: towards a comparison. Linguistic Typology 8: 243-285.

Haspelmath, Martin. 1997. Indefinite pronouns. Oxford: Clarendon Press.

Haspelmath, Martin. 2004. On directionality in language change with particular reference to grammaticalization. In Olga Fischer, Muriel Norde \& Harry Perridon, eds. Up and down the cline - The nature of grammaticalization. Amsterdam: John Benjamins, 17-44.

Heine, Bernd \& Tania Kuteva. 2002. World lexicon of grammaticalization. Cambridge: Cambridge University Press.

Heine, Bernd \& Tania Kuteva. 2005. Language contact and grammatical change. Cambridge: Cambridge University Press.

Hopper, Paul J. 1986. Some discourse functions of classifiers in Malay. In Craig, ed. 309-325.

Horrocks, Geoffrey. 1997. Greek. A history of the language and its speakers. London: Longman.

Kuhlmann, Peter. 1999. Heis als Indefinitpronomen im Griechischen in diachroner Sicht. Glotta LXXIV: 76-93.

Kühner, Raphael. 1898. Ausführliche Grammatik der griechischen Sprache. Zweiter Teil: Satzlehre. Hannover-Leipzig: Hahnsche Buchhandlung.

Lee, John A. L. 1983. A lexical study of the Septuagint version of the Pentateuch. Chico, CA: Scholars Press.

Porter, Stanley E. 1989. Verbal aspect in the Greek of the New Testament, with reference to tense and mood. Frankfurt am Main: Peter Lang.

Sands, Kristina. 1995. Nominal classification in Australia. Anthropological Linguistics 37: 247-346.

Sansò, Andrea. To appear. Grammaticalization paths or prototype effects? A history of the agentive reflexive passive in Italian. In Tanja Mortelmans, ed. Prototypes and grammaticalization: grammaticalization as prototype? [Special issue of Language Sciences.]

Senft, Gunter, ed. 2000. Systems of nominal classification. Cambridge: Cambridge University Press.

Smith, Ian \& Steve R. Johnson. 2000. Kugu Nganhcara. In Robert M. W. Dixon \& Barry J. Blake, eds. The handbook of Australian languages. Vol. 5. Oxford: Oxford University Press, 357-489. 
Thackeray, Henry. 1909. A grammar of the Old Testament in Greek. Cambridge: Cambridge University Press.

Walsh, Michael. 1997. Nominal classification and generics in Murrinhpatha. In Mark Harvey \& Nicholas Reid, eds. Nominal classification in Aboriginal Australia. Amsterdam: John Benjamins, 255-292.

Weiss, Daniel. 2004. The rise of an indefinite article: the case of Macedonian eden. In Walter Bisang, Nikolaus P. Himmelmann \& Björn Wiemer, eds. What makes grammaticalization? A look from its fringes and its components. Berlin: Mouton de Gruyter, 139-165.

Wellhausen, Julius. 1911². Einleitung in die drei ersten Evangelien. Berlin: Georg Reimer.

Wilkins, David P. 2000. Ants, ancestors and medicine: a semantic and pragmatic account of classifier constructions in Arrernte (Central Australia). In Senft, ed. $147-216$.

Author's address

Dipartimento di Diritto Romano, Storia e Filosofia del Diritto

received: 20 March 2008

Università dell'Insubria

revision invited: 28 June 2008

Como, Italy

e-mail: asanso@gmail.com

revised version received: 8 August 2008

accepted: 10 October 2008 



\section{SOCIETAS LINGUISTICA EUROPAEA}

Founded in 1966 for the fostering and advancement, in European countries and elsewhere, of the scientific and scholarly study of language in all its aspects.

http://www.societaslinguistica.eu

Since the elections of 2008 in Forlì the following persons now serve as officers or members of Committees:

President:

Vice-President:

President-Elect

Secretary/Treasurer:

Editor FoL:

Editor FoLH:

Executive Committee:
Pier Marco Bertinetto, Pisa (2009)

Bernard Comrie, MPI-EVA, Leipzig (2009)

Hubert Cuyckens, Leuven (2009)

Dik Bakker, Amsterdam \& Lancaster

Teresa Fanego, Santiago de Compostela

Hans Henrich Hock, Urbana-Champaign

the preceding and

Markku Filppula, Joensuu (2009)

Marianne Mithun, Santa Barbara (2009)

Isabella Buniyatova, Kiev (2010)

Marianne Kilani-Schoch, Lausanne (2010)

Anna Siewierska, Lancaster (2011)

Mario Squartini, Torino (2011)

Nominating Committee: $\quad$ Gabriele Diewald, Hanover (2009)

Silvia Luraghi, Pavia (2010)

Katarzyna Dziubalska-Kolaczyk, Poznan (2011)

Pavol Štekauer, Košice (2012)

José Pinto de Lima, Lisbon (2013)

Scientific Committee: $\quad$ Christopher Beedham, St Andrews (2009)

Teresa Fanego, Santiago de Compostela (2010)

Letizia Vezzosi, Perugia (2011)

Ursula Doleschal, Klagenfurt (2012)

Edith Moravcsik, Milwaukee (2013)

Conference Manager: Bert Cornillie, Leuven

To join the SLE and receive FOLIA LINGUISTICA please consult the SLE website. Dues por personal membership in the society are EUR 30.00 per year.

For institutional subcriptions please contact MOUTON DE GRUYTER at the following address:<degruyter@de.rhenus.com>. 


\section{FoL 4312009}

\section{Table of contents}

\section{Articles}

Christopher S. Butler (Swansea): Criteria of adequacy in functional linguistics 1

Seppo Kittilä (Helsinki): Causative morphemes as non-valency increasing devices 67

Andrea Sansò (Como): Men, women and birds. An embryonic system of noun classification in Ancient Greek 95

Pieter A. M. Seuren (MPI-Psycholinguistics) \& Camiel Hamans: Semantic conditioning of syntactic rules: evidentiality and auxiliation in English and Dutch 135

An Van linden (Leuven) \& Kristin Davidse (Leuven): The clausal complementation of deontic-evaluative adjectives in extraposition constructions: a synchronic-diachronic approach 171

\section{Review article}

Maria Koptjevskaja-Tamm (Stockholm): Irina Nikolaeva, ed. Finiteness.

Theoretical and empirical foundations $\mathbf{2 1 3}$

\section{Book reviews}

Ulrich Detges \& Richard Waltereit, eds.: The paradox of grammatical change. Perspectives from Romance. Reviewed by Maj-Britt Mosegaard-Hansen (Manchester) 251

Olga Fischer: Morphosyntactic change: functional and formal perspectives. Reviewed by Graeme Trousdale (Edinburgh) 256

\section{Miscellanea}

Conference announcement: 42nd Annual Meeting of the Societas Linguistica Europaea 265

Publications received 266 